\title{
Alleviation of soil salinity on physiological and agronomic traits of rice cultivars using Arbuscular mycorrhizal fungi and Pseudomonas strains under field conditions
}

\author{
Firouz Norouzinia $^{1}$, Mohammad Hossein Ansari ${ }^{1 *}$, Hashem Aminpanah ${ }^{1}$, Saeed Firouzi ${ }^{1}$ \\ ${ }^{1}$ Department of Agronomy, Rasht Branch, Islamic Azad University, Rasht, Iran. E-mail: wheat.genetic@ gmail.com, \\ mansari@iaurasht.ac.ir,aminpanah@iaurasht.ac.ir, firoozi@iaurasht.ac.ir \\ * corresponding author
}

Received: 28/10/2019; Accepted: 06/03/2020.

\section{ABSTRACT}

Rice cultivation in Iran has a special place and its cultivation area is about 640,000 ha. Soil salinization is one of the most factor in reducing of grain yields and cultivation of paddy rice. Currently, half of Iran's cultivated lands (9.5 million ha) are affected by salinity, which has a major impact on crop yields. For this purpose, an field experiment conducted with the use of microorganisms (Pseudomonas putida strain S34, Pseudomonas fluorescens strain R167, Arbuscular mycorrhizal fungi (AMF) (Rhizophagus irregularis), co-inoculation of P.putida + P.fluorescens + AMF, and a non-inoculated treatment as control) on two rice cultivars (Hashemi and Gilane) in saline and normal soil in north of Iran during the 2018 and 2019. The results showed interactions of microorganisms and soil condition could alleviate the adverse effects of salinity by decreasing $\mathrm{H}_{2} \mathrm{O}_{2}$ (14-71\% in normal soil and 44$281 \%$ in saline soil) and increasing catalase (CAT) activity (39.5-65\% in Gilane and 45-61\% in Hashemi), proline (17-46\% in Gilane and 13.5-52\% in Hashemi) and nitrogen (N) concentrations (12-27\% in normal soil and 7-23\% in saline soil) of leaves. Also microorganisms significantly increased tiller, panicle and grain number plant ${ }^{-1}$, and biological and grain yield (23-44.5\% and 32.5-56\% in normal and saline soil, respectively). Furthermore, the greatest mitigating effects were observed in treated by P.putida + P.fluorescens + AMF plants. This study indicated that P.putida + P.fluorescens + AMF synergistically mitigate harmful impacts of soil salinity in rice cultivars.

Keywords: Catalase, $\mathrm{H}_{2} \mathrm{O}_{2}$, Mycorrhizal Fungi, Pseudomonas, Rice cultivars, Saline soil.

\begin{abstract}
Alívio da salinidade do solo nas características fisiológicas e agronômicas de cultivares de arroz utilizando fungos micorrízicos arbusculares e cepas de Pseudomonas em condições de campo
\end{abstract}

\section{RESUMO}

O cultivo de arroz no Irã tem um lugar de destaque e sua área de cultivo é de cerca de 640.000 ha. A salinização do solo é um dos principais fatores na redução da produção de grãos e no cultivo do arroz. Recentemente, metade das terras cultivadas do Irã (9,5 milhões de ha) é afetada pela salinidade, que tem um grande impacto no rendimento das culturas. Para esse fim, um experimento de campo foi conduzido com o uso de microrganismos [Pseudomonas putida estirpe S34, Pseudomonas fluorescens estirpe R167, fungos micorrízicos arbusculares (FMA) (Rhizophagus irregularis), co-inoculação de P.putida + P.fluorescens + FMA e um tratamento não inoculado como controle] em dois cultivares de arroz (Hashemi e Gilane) em solo salino e solo normal no norte do Irã, durante os anos de 2018 e 2019. Os resultados mostraram interações entre os fatores microrganismos e condições do solo que poderiam aliviar os efeitos adversos da salinidade pelo decréscimo de $\mathrm{H}_{2} \mathrm{O}_{2}$ (14-71\% no solo normal e 44-281\% no solo salino) e aumento da atividade da catalase (CAT) (39,5-65\% em Gilane e 45-61\% em Hashemi), da prolina (17$46 \%$ em Gilane e 13,5-52\% em Hashemi) e do nitrogênio (N) (12-27\% no solo normal e 7-23\% no solo salino) nas folhas. Os microrganismos, também, aumentaram significativamente o número de perfilhos, panículas e grãos por planta $^{-1}$, rendimentos biológicos e de grãos (23-44,5\% e 32,5-56\% no solo normal e salino, respectivamente). Além disso, os maiores efeitos mitigadores foram observados nas plantas tratadas com P.putida + P.fluorescens + FMA. Este estudo indicou que P.putida + P.fluorescens + FMA atenuam sinergicamente os impactos nocivos da salinidade do solo em cultivares de arroz.

Palavras-chave: Catalase, $\mathrm{H}_{2} \mathrm{O}_{2}$, Fungos micorrízicos, Pseudomonas, Cultivares de arroz, Solo salino. 


\section{Introduction}

Rice (Oryza sativa L.) being the staple food of more than half of the world population, has been encountered higher production against increasingly demand (Kaur et al., 2016). Involving more than 640000 hectares of cultivation area plays important role in human feeding in Iran (Database of jahad-e-agriculture ministry, 2018). Salinity is one of the environmental stresses not only threatens plant growth but also determines distribution of the crops among various ecosystems (Ismail and Horie, 2017). Nowadays, more than half of the cropland area of the country ( 9.5 million hectares) suffers from salinity which mainly results in reduction of crop yield and cultivation area (Nabiollahi et al., 2017).

For many years, salinity has been considered as the most important limiting factor for rice cultivation worldwide (Ponnamperuma and Bandyopadhya, 1979; McWilliam, 1986). This crop is sensitive to salinity and the highest rate occurs during seedling and flowering stages (Hosseini et al., 2012). Also, high rates of evapotranspiration over the cropping season results in the severe damage of this stress (Zhang et al., 2010). Yield components of rice are intensely affected by salinity so that ear height, number of spikelet, single seed weight, and seed weight per plant, seed weight per ear, number of ear, fertility, and harvest index are significantly influenced by salinity (Rahman et al., 2016). Furthermore, various reports indicate increasing of the accumulation of ammonium and decreasing of the chlorophyll content of leaves on account of salinity stress (Hoai et al., 2005). Some findings are present in literature showing the high amounts of salts accumulated in plants and low rates of nitrogen absorption and biomass production (Ali et al., 2004; Singh and Sarkar, 2014; Jan et al., 2018).

Salinity negatively impacts on number of tillers prior to spike emergence, and on number and weight of spike from three foliage through fertilization stage (Zeng et al., 2003) but without effect on fertility percent and weight of stem and whitened seed (Gay et al., 2010). Castillo et al. (2007) illustrated that osmotic stress impact on ear fertility percent, 100 seed weight and yield over reproductive stage significantly is higher than growth stage.

Oxidative stress is among physiological damages of salinity (Zhang et al., 2010). This stress is considered as a complicated physiological and phenological phenomenon which is caused by overproduction and accumulation of reactive oxygen species (ROS) occurred in higher plants (Ismail and Horie, 2017). Different types of ROS not only damage cells, but react as secondary messengers and play important role in transferring stress signs (Khaliq et al., 2015). In order to alleviate oxidative stress damages, plants benefit from anti-oxidation defense mechanisms including non-enzymatic compounds like carotenoids, tocopherol, flavonoids and also enzymatic substances such as superoxide dismutase (SOD), catalase (CAT), peroxidase (POX), ascorbate peroxidase (APX) and poly phenol oxidase (PPO). Plants with elevated levels of anti-oxidants possess high resistance against oxidative stress (Kibria et al., 2017) however; it seems that AMF would be a useful, inexpensive, sustainable and environmentally friendly substance to cope with salinity stress (Jiang et al., 2017; Luginbuehl et al., 2017) by increasing nutrient elements absorption efficiency as a result of symbiosis correlation with plant root system.

Arbuscular mycorrhizal fungi (AMF, Phylum Glomeromycota) are important components of soil microbial communities. AMF form mutualistic associations with roots of most terrestrial plants, including many agricultural crops. In many agricultural plants, these mutualistic associations have shown the potential to increase crop productivity, thereby playing a key role in the functioning and sustainability of agroecosystems (Gianinazzi et al., 2010). The most important function of these symbiotic associations involves the transfer of nutrients such as organic carbon (C), in the form of sugars and lipids (Jiang et al., 2017; Luginbuehl et al., 2017), to the fungi by the plants, and the transfer of phosphorus $(\mathrm{P})$ and nitrogen $(\mathrm{N})$ to the plants by the fungi (Smith and Read, 2008). AMFmediated improvement in mineral uptake may lead to increased growth and development of plants, and may confer resistance to abiotic and biotic stress (Smith and Read, 2008; Gianinazzi et al., 2010; Liu et al., 2015). In addition to these benefits to plants, AMF may improve soil structure, ameliorate drought and salinity stress, and affect the diversity of plant communities (Mummey and Rillig, 2006; Smith et al., 2009; van der Heijden, 2010). The benefits of AMF may be critical to increasing agricultural yields and productivity in a low-input manner.

Various reports illustrate participation of plant growth promoter bacteria (PGPR) in dissolution of nutrients like phosphorous, potassium and iron and their ability to produce phytohormones, vitamins and siderophores (Vessey, 2003; Asadi Rahmani et al., 2012). If PGPR are inoculated along with $\mathrm{AMF}$, then result in promoting plant growth and development by dissolution of nutrients like phosphorous from both mineral and organic sources and their transfer to the rhizosphere which in turn, improve AMF establishment (Watanarojanaporn et al., 2013; Hata et al., 2016; Luginbuehl et al., 2017).

In recent years, many paddy soils have experienced salinity and this has been caused severe yield loss in crop like rice. In general, salinity has become a problem in cropping fields especially under unconventional irrigations (Kamyab-Talesh et al., 2014). In this regard, salinization of some seasonal and permanent rivers have 
been considered as the threats of salinity problems in rice fields in Northern Iran. Attempts for decreasing soil salinity with current methods are usually expensive (Navabian and Aghajani, 2012). Therefore, the present study was conducted to improve physiological and agronomic traits of rice cultivars in a paddy saline soil using an inexpensive and useful method in north of Iran.

\section{Material and Methods}

\subsection{Experimental site and plant growth conditions}

The two field experiments were carried out at the experimental flooded paddy rice field of Islamic Azad University, Astara, Gilan province, Iran (38 $21^{\prime} \mathrm{N} 48^{\circ}$ 50' E, $25 \mathrm{~m}$ a.s.1.) in saline and normal soil at 2018 and 2019. The region is characterized by the humid subtropical climate, with an annual average air temperature of $15.9{ }^{\circ} \mathrm{C}$, precipitation of $1,429 \mathrm{~mm}$, sunshine of $1,866 \mathrm{~h}$, and frost-free period of 331 days. To simplify the comparison of the growing season weather, we considered the monthly total precipitation and temperature from May through August at the Rasht Agricultural Research Farm (Figure 1).

In order to determine soil characteristics, in both years soils (saline and normal soils) sampling were performed before the experiment. To do this, field soils sampling were done from the depth of $0-30 \mathrm{~cm}$ in eight spots. Then the collected samples sent to the laboratory in order to determine soil texture and the chemical composition. Properties of experimental soil samples are given in Table 1.

In the saline field, soil electrical conductivity (EC) increased from May with increasing air temperature, evaporation and solute uptake as shown in Figure 2.
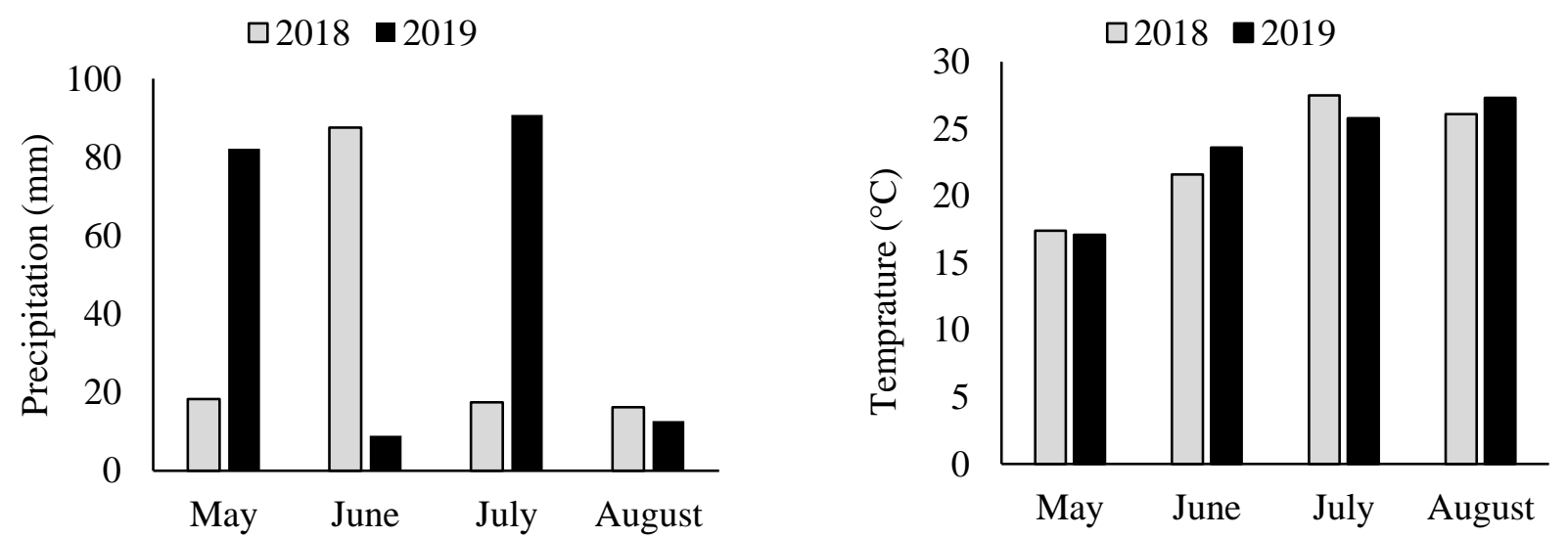

Figure 1. Monthly precipitation and temperature from May to August for the growing season (2018-2019) at the Astara experimental field.

Table 1. Soil Physical and chemical characteristics of the soil at 2018 and 2019

\begin{tabular}{|c|c|c|c|c|c|c|c|c|c|c|c|}
\hline & \multirow[t]{2}{*}{ Year } & \multirow{2}{*}{$\begin{array}{l}\text { Potential } \\
\text { of } \\
\text { Hydrogen } \\
\text { (pH) }\end{array}$} & \multirow{2}{*}{$\begin{array}{c}\text { Electrical } \\
\text { Conductivity } \\
(\mathrm{EC}) \\
\left.(\mathrm{dS} \mathrm{m})^{-1}\right)\end{array}$} & $\begin{array}{c}\text { Organic } \\
\text { Carbon } \\
(\mathrm{OC})\end{array}$ & $\begin{array}{c}\text { Total } \\
\text { Nitrogen } \\
(\mathrm{N}) \\
\end{array}$ & $\begin{array}{l}\text { Available } \\
\text { Phosphorus } \\
\text { (P) }\end{array}$ & $\begin{array}{c}\text { Available } \\
\text { Potassium } \\
\text { (K) }\end{array}$ & $\begin{array}{c}\text { Lime } \\
\left(\mathrm{CaCO}_{3}\right)\end{array}$ & Sand & Silt & Clay \\
\hline & & & & \multicolumn{2}{|c|}{$(\%)$} & \multicolumn{2}{|c|}{$\left(\mathrm{mg} \mathrm{kg}^{-1}\right)$} & \multicolumn{4}{|c|}{$(\%)$} \\
\hline \multirow{2}{*}{ Normal } & 2018 & 6.18 & 0.678 & 2.34 & 0.218 & 19.92 & 234 & 4.0 & 17.3 & 37.5 & 45.2 \\
\hline & 2019 & 6.4 & 0.509 & 2.01 & 0.241 & 17.51 & 251 & 4.4 & 18.4 & 37 & 44.6 \\
\hline \multirow{2}{*}{ Saline } & 2018 & 6.3 & 1.88 & 1.75 & 0.175 & 15.6 & 161.7 & 10.1 & 17.3 & 32.6 & 50.1 \\
\hline & 2019 & 7.1 & 1.76 & 1.48 & 0.132 & 16.13 & 172.3 & 9.5 & 19.9 & 30.4 & 49.7 \\
\hline
\end{tabular}

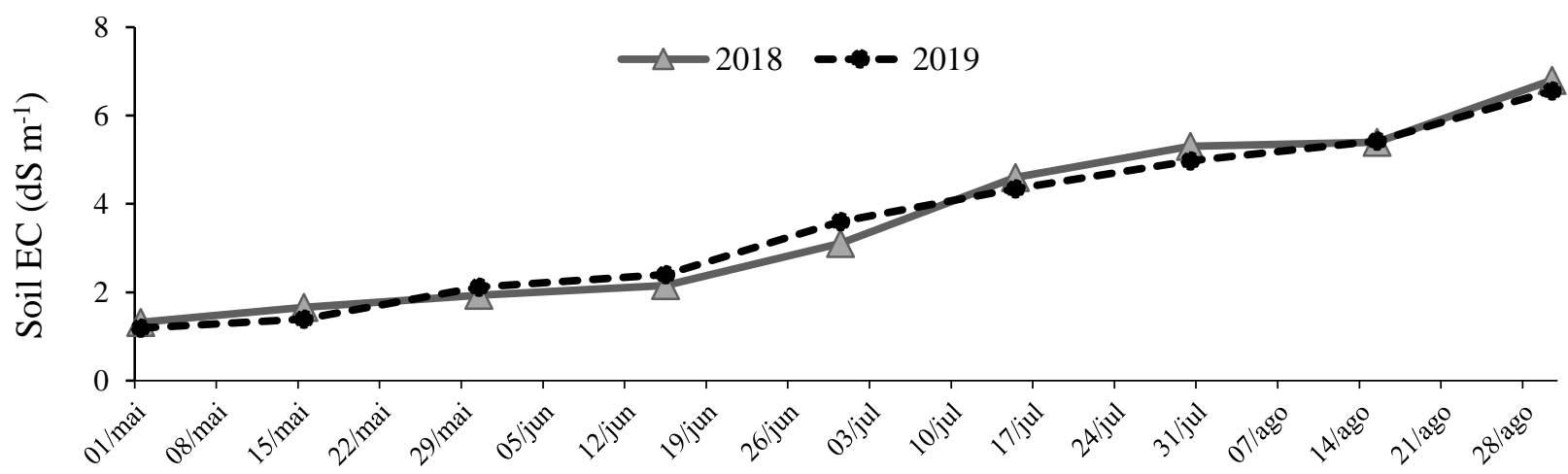

Figure 2. Trends changes of soil salinity (EC) during plant growth in saline soil. 


\subsection{Experimental Design and Treatments}

The experiments were carried out in a split plot factorial trial based on Randomized Complete Block Design (RCBD) with three replications in two different soils. Experimental factors consisted of soil condition (saline and normal soil) as main plot and rice cultivars (Hashemi and Gilane), microorganisms (Pseudomonas putida strain S34, Pseudomonas fluorescens strain R167, Arbuscular mycorrhizal fungi (AMF) (Rhizophagus irregularis), co-inoculation of Pseudomonas putida + Pseudomonas fluorescens + AMF, and a non-inoculated treatment as control).

\subsection{Bacterial Inoculant Preparation and Sowing Conditions}

Microorganisms isolated from the roots of field-grown rice were kindly provided by the Soil Microbiology Collection of Iran at Soil and Water Research Institute (SWRI).

The rice cultivars used in this experiment were Hashemi and Gilane, for which the growth period ranges from 118 to 140 days from sowing date to physiological maturity. Consistent with the lowland paddy field practices in north of Iran, rice seeds were sown in a nursery seedbed on 10 April. Before sowing, rice seeds were soaked by Arabic gum and active bacteria were added to seeds. After seeds inoculation with $1000 \mathrm{ml}$ of bacterial suspension $\left(10^{8} \mathrm{CFU} \mathrm{ml}^{-1}\right)$, seeds were dried on a surface sterilized plastic sheet in laminar flow. Additionally, for non-inoculation treatments (control) the rice seeds were treated with inoculant-free autoclaved saline solution $(0.85 \% \mathrm{NaCl})$.

The AMF inoculum contained colonized root fragments, sand, AMF hyphae and spores. The inoculum was blended with an inert material for solution and homogenizing the distribution in the soil. A 50-g portion of inoculum was added to each seed tray at sowing time just below the seeds (Vázquez et al., 2002).

Rice seedlings (27-day-old) transplanted into the experimental plots. Seedlings were manually transplanted on 17 May at a hill with $0.20 \times 0.20 \mathrm{~m}$ spacing, with three seedlings per hill. The plot size was $12 \mathrm{~m}^{2}(3 \mathrm{~m} \times 4 \mathrm{~m})$ with 300 hills per plot. All plots were separated by $60 \mathrm{~cm}$ ridges to stop the movement of water/bacteria. Weeds were controlled by hand weeding during the growth season. The permanent flood water level was maintained at $10 \mathrm{~cm}$ during the rice growing period.

\subsection{Plant sampling}

In growth stages of rice at $\mathrm{T}$ (tillering), $\mathrm{P}$ (panicle differentiation), $\mathrm{H}$ (heading), $\mathrm{D}$ (soft dough) eight randomly chosen plants were removed from each plot and in the flag leaves, total chlorophyll (chlorophyll a + b) content were determined by Arnon (1949) method. At maturity stage, rice grain yield (based on $14 \%$ humidity) was determined from $2.5 \mathrm{~m}^{2}$ per plot. Moisture content of grains was measured using a digital grain moisture meter (Model GMK- 303R5-Korea) and grain yield per plot was calculated as ((100 - moisture content of the sample) $\times$ fresh grain weight)/86 to convert the sample to $14 \%$ moisture content. Yield components, that is, number of tiller, number of filled and unfilled grains and 1000-grain weight, were determined from 12 plants (excluding the border ones) sampled randomly from each plot. To determine aboveground biomass, a $1 \mathrm{~m}^{2}$ sample from each plot was randomly chosen and placed in a separate paper bag, dried at $72{ }^{\circ} \mathrm{C}$ for $48 \mathrm{~h}$, weighed, and expressed as the biological yield (dry weight of aboveground plant) per hectare. Harvest index was the proportion (percentage) of filled grain weight to biological yield.

In flowering stage, three randomly chosen plants were removed from each plot for measuring leaf $\mathrm{N}$ concentration, flag leaves were grounded to pass through a 1-mm sieve. $\mathrm{N}$ concentration was determined using micro-Kjeldahl (Emami, 1996).

At soft dough stage the CAT activity (EC 1.16.1.6) was assayed according to the procedure of Aebi (1983) by monitoring the rate of decomposition of $\mathrm{H}_{2} \mathrm{O}_{2}$ at 240 $\mathrm{nm}$ in the reaction mixture consisting of $50 \mathrm{mM}$ potassium phosphate buffer, $10 \mathrm{mM} \mathrm{H}_{2} \mathrm{O}_{2}$ and the crude enzyme solution. The content of $\mathrm{H}_{2} \mathrm{O}_{2}$ was determined according to Loreto and Velikova (2001).

Proline content in leaf tissues was measured via reaction with ninhydrin (Bates et al., 1973). For colorimetric determinations, a solution of proline, ninhydrin acid and glacial acetic acid (1:1:1) was incubated at $90{ }^{\circ} \mathrm{C}$ for $1 \mathrm{~h}$. The chromophore was extracted using $2 \mathrm{ml}$ of toluene and its absorbance at $520 \mathrm{~nm}$ was determined by a BioMate spectrophotometer (Shimadzu UV-160, Japan).

\subsection{Statistical analysis}

All data were subjected to analysis of variance (ANOVA) using SAS 9.3 software. When F test indicated statistical significance at $\mathrm{P}<0.01$ or $\mathrm{P}<0.05$, the least significant difference (LSD) was used to separate the means.

\section{Results and Discussion}

\subsection{Total Chlorophyll content}

Results of the chlorophyll content over the growing season revealed that in most treatments, this trait was increased until grain filling period and then was decreased in soft dough level. Leaf chlorophyll content of Hashemi cultivar changed from $6.13 \mathrm{mg} \mathrm{g}^{-1} \mathrm{FW}$ (control) to $8.89 \mathrm{mg} \mathrm{g}^{-1} \mathrm{FW}$ (Pseudomonas fluorescens) and from $2.30 \mathrm{mg} \mathrm{g}^{-1} \mathrm{FW}$ (control) to $4.93 \mathrm{mg} \mathrm{g}^{-1} \mathrm{FW}$ (AMF) in normal and saline soils, respectively (Figure 3). 
Such rates for Gilane cultivar changed from $3.05 \mathrm{mg} \mathrm{g}^{-1}$ FW (control) to $6.13 \mathrm{mg} \mathrm{g}^{-1} \mathrm{FW}$ (P. fluorescens) and from $3.04 \mathrm{mg} \mathrm{g}^{-1} \mathrm{FW}$ (control) to $4.45 \mathrm{mg} \mathrm{g}^{-1} \mathrm{FW}$ (AMF) in normal and saline soils, respectively (Figure 4).

In stage of panicle differentiation, leaf chlorophyll content of Hashemi cultivar changed from $5.71 \mathrm{mg} \mathrm{g}^{-1}$ FW (control) to $10.29 \mathrm{mg} \mathrm{g}^{-1} \mathrm{FW}$ (P.fluorescens) and from $2.30 \mathrm{mg} \mathrm{g}^{-1} \mathrm{FW}$ (control) to $3.95 \mathrm{mg} \mathrm{g}^{-1} \mathrm{FW}$ (AMF) in normal and saline soils, respectively (Figure 3 ). In Gilane cultivar, it was changed from $5.21 \mathrm{mg} \mathrm{g}^{-1} \mathrm{FW}$ (control) to $9.83 \mathrm{mg} \mathrm{g}^{-1} \mathrm{FW}$ (P.fluorescens) and from $3.92 \mathrm{mg} \mathrm{g}^{-1} \mathrm{FW}$ (co-inoculated) to $5.27 \mathrm{mg} \mathrm{g}^{-1} \mathrm{FW}$ (P.fluorescens) in normal and saline soils, respectively. In stage of heading, leaf chlorophyll content of Hashemi cultivar changed from $7.09 \mathrm{mg}$ g-1 FW (control) to 12.7 mg g-1 FW (P.fluorescens) and from $2.30 \mathrm{mg}$ g-1 FW (control) to $4.63 \mathrm{mg}$ g-1 FW (MIX) in normal and saline soils, respectively (Figure 3).

In Gilane cultivar, it was changed from $7.82 \mathrm{mg}$ g-1 FW (control) to $9.46 \mathrm{mg}$ g-1 FW (P.fluorescens) and from $3.41 \mathrm{mg}$ g-1 FW (co-inoculated) to $6.59 \mathrm{mg}$ g-1 FW (Pseudomonas putida) in normal and saline soils, respectively (Figure 4).

In most treatments, leaf chlorophyll content was increased until heading stage and significantly decreased towards soft dough but in Hashemi cultivar treated with AMF and P.fluorescens under saline soil, this rate was decreasing from heading to soft dough (Figure 4).

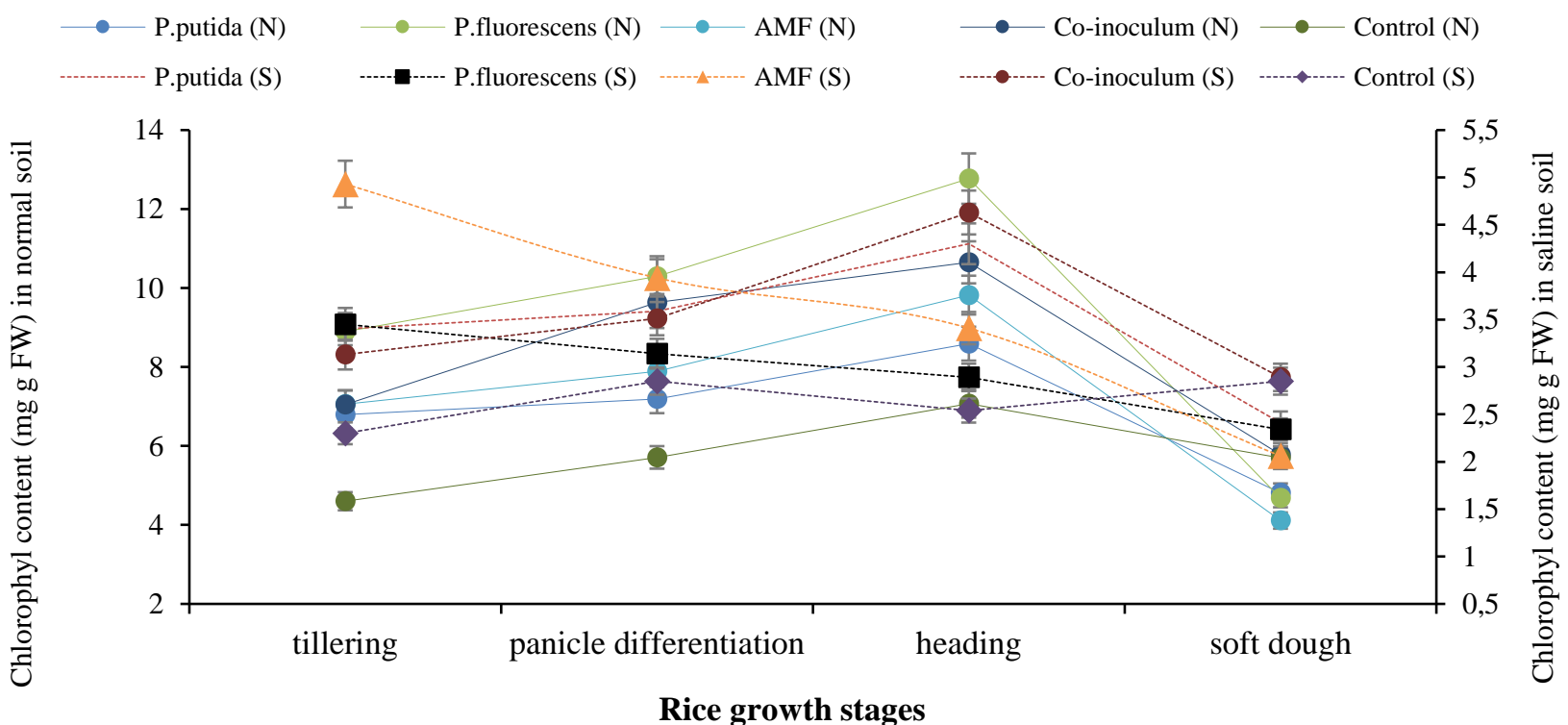

Figure 3. Mean comparison of effect of saline soil and microorganisms on total chlorophyll content in growth stages of rice (Hashemi).

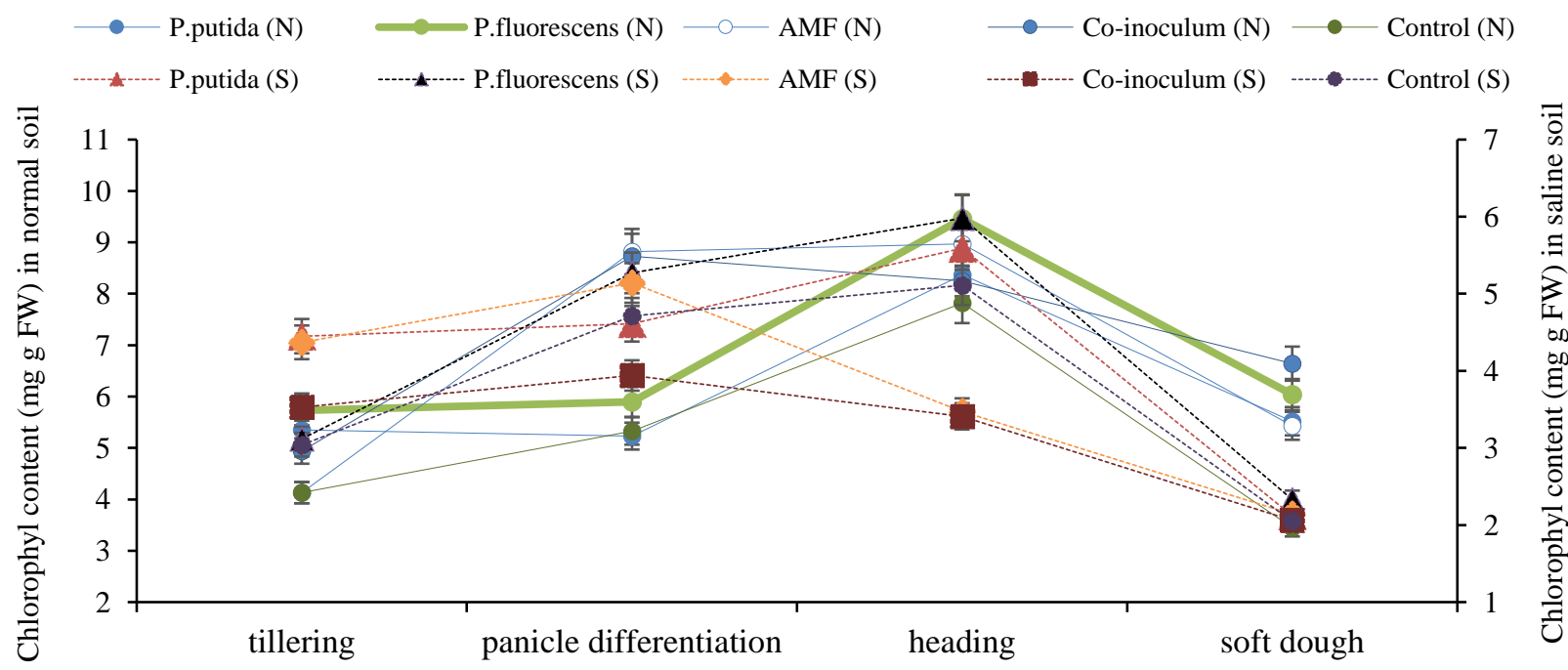

\section{Rice growth stage}

Figure 4. Mean comparison of effect of saline soil and microorganisms on total chlorophyll content in growth stages of rice (Gillaneh). 


\section{2. $\mathrm{H}_{2} \mathrm{O}_{2}$ content}

Based on the results, only the interaction effect of microorganisms $\times$ cultivars was significant on leaf $\mathrm{H}_{2} \mathrm{O}_{2}$ content (Table 2). In all treatments, soli salinity resulted in increasing of this trait but this increment was lower in those treated with microorganisms. Although in both soils, plants treated with microorganisms decreased $\mathrm{H}_{2} \mathrm{O}_{2}$ content than control but, the lowest rate was achieved from co-inoculated (Figure 5).

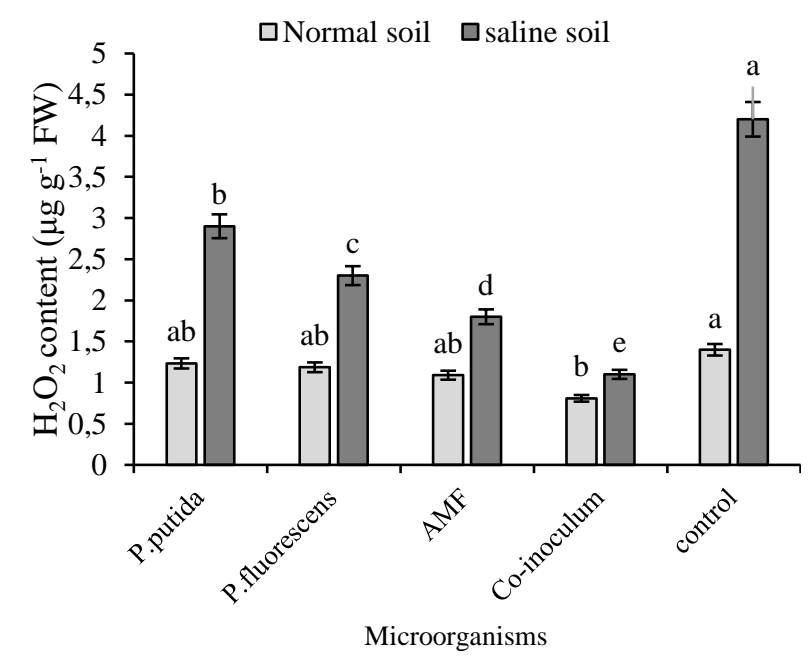

Figure 5. Mean comparison of effect of soil condition $\times$ microorganisms on $\mathrm{H}_{2} \mathrm{O}_{2}$ content.

\subsection{CAT activity}

Soil salinity increased CAT activity in both years and cultivars, and significant difference was observed among microorganisms (Table 2). Treatments showed different reactions to cultivars and soil conditions. Although inoculated plants in normal soil showed more activity than control (in first year 6-31\% and second year 9-47\%) but the highest CAT activity was achieved from inoculation with P.fluorescens (Gilane) and with P.putida (Hashemi) (Figure 6A).

In saline soil, plants treated with Pseudomonas had not significant difference with control or showed lower CAT activity while AMF and co-inoculated plants gained the highest activity than control so that, this rates for Gilane cultivar in first and second year were $17-30 \%$ and $62-68 \%$ and in Hashemi cultivar, the rates were $45-65 \%$ and $45-57 \%$ for first and second years, respectively (Figure 6B).

\subsection{Proline content}

Soil salinity increased proline synthesis from 7.3 $\mu \mathrm{mol} \mathrm{g}{ }^{-1} \mathrm{FW}$ (mean of treatments in normal soil) to 61.6 $\mu \mathrm{mol} \mathrm{g}{ }^{-1} \mathrm{FW}$ (mean of treatments in saline soil) and most treatments had superiority to control in both years and cultivars. In normal soil, the highest leaf proline content of Gilane cultivar in both years was achieved by applying P.fluorescens and by P.putida in Hashemi cultivar (Figure 7A). In saline soil, both inoculated cultivars in both years showed superiority to control of about 29-59\% (first year) and 5-33\% (second year) for Gilane and 17$41 \%$ (first year) and $10-63 \%$ (second year) for Hashemi cultivar. The highest leaf proline content was observed in inoculation with P.putida followed by co-inoculated plants (Figure 7B).

Table 2. Analysis of variance of soil condition $\times$ microorganisms effect on agronomic traits of rice cultivars in 2018 and 2019

\begin{tabular}{|c|c|c|c|c|c|c|c|}
\hline \multirow{3}{*}{ S.O.V } & \multicolumn{6}{|c|}{ MS (Mean Square) } & \multirow{3}{*}{$\begin{array}{c}\text { Fertile } \\
\text { tiller number }\end{array}$} \\
\hline & \multicolumn{4}{|c|}{ In flag leaf } & \multirow{2}{*}{$\begin{array}{l}\text { Plant } \\
\text { height }\end{array}$} & \multirow{2}{*}{$\begin{array}{c}\text { Stem } \\
\text { diameter }\end{array}$} & \\
\hline & CAT & $\mathrm{H}_{2} \mathrm{O}_{2}$ & Proline & $\mathrm{N}$ & & & \\
\hline $\bar{Y}$ & $94635 * *$ & $290 \mathrm{~ns}$ & $474333 n s$ & $0.000018 n s$ & $12.5 \mathrm{~ns}$ & $0.014 \mathrm{~ns}$ & $93.7 \mathrm{~ns}$ \\
\hline $\mathrm{S}$ & $222224 * *$ & $10562 * *$ & $602855910 * *$ & $0.0087 * *$ & $183^{* *}$ & $0.170 \mathrm{~ns}$ & $12412 * *$ \\
\hline Error 1 & 609 & 9802 & 474333 & 0.00042 & 33.6 & 0.258 & 302 \\
\hline $\mathrm{C}$ & $28241 *$ & $5381 \mathrm{~ns}$ & $50974327 * *$ & $0.0051 * *$ & $115^{* *}$ & $0.159 \mathrm{~ns}$ & $1118 * *$ \\
\hline M & $31758 * *$ & $803 * *$ & $260679398 * *$ & $0.00125 * *$ & $106 * *$ & $0.174 \mathrm{~ns}$ & $3584 * *$ \\
\hline $\mathrm{S} \times \mathrm{Y}$ & $17293 *$ & $201.3 \mathrm{~ns}$ & $167881389 * *$ & $0.0076 * *$ & $123 * *$ & $0.29 *$ & $11016 * *$ \\
\hline $\mathrm{C} \times \mathrm{Y}$ & $834 \mathrm{~ns}$ & $191 \mathrm{~ns}$ & $1371306 * *$ & $0.000033 \mathrm{~ns}$ & $33.2 \mathrm{~ns}$ & $0.081 \mathrm{~ns}$ & $69.1 \mathrm{~ns}$ \\
\hline $\mathrm{M} \times \mathrm{Y}$ & $23670 * *$ & $158.4 \mathrm{~ns}$ & $2375 \mathrm{~ns}$ & $0.000096 \mathrm{~ns}$ & $71.7 \mathrm{~ns}$ & $0.007 \mathrm{~ns}$ & $1945 * *$ \\
\hline $\mathrm{S} \times \mathrm{C}$ & $184 \mathrm{~ns}$ & $122.5 \mathrm{~ns}$ & $16058 \mathrm{~ns}$ & $0.000266 \mathrm{~ns}$ & $106^{* *}$ & $0.158 \mathrm{~ns}$ & $1787 * *$ \\
\hline $\mathrm{S} \times \mathrm{M}$ & $19881 * *$ & $1496 * *$ & $153748570 * *$ & $0.00049 \mathrm{~ns}$ & $487 * *$ & $0.00048 n s$ & $83.2 \mathrm{~ns}$ \\
\hline $\mathrm{C} \times \mathrm{M}$ & $5025 \mathrm{~ns}$ & $67.7 \mathrm{~ns}$ & $399448732 * *$ & $0.00376^{* *}$ & $1450 * *$ & $0.002 \mathrm{~ns}$ & $2343 * *$ \\
\hline $\mathrm{M} \times \mathrm{C} \times \mathrm{S}$ & $79088 * *$ & $251.6 n s$ & $1479386 * *$ & $0.00674 * *$ & $591 * *$ & $0.0036 \mathrm{~ns}$ & $1937 * *$ \\
\hline $\mathrm{Y} \times \mathrm{S} \times \mathrm{C}$ & $67401 * *$ & $81.59 \mathrm{~ns}$ & $456206137 * *$ & $0.000292 \mathrm{~ns}$ & $244 * *$ & $32.1 * *$ & $5133 * *$ \\
\hline $\mathrm{Y} \times \mathrm{S} \times \mathrm{M}$ & $36399 * *$ & $320.1 \mathrm{~ns}$ & $221959528 * *$ & $0.000482 \mathrm{~ns}$ & $192 * *$ & $0.0536 \mathrm{~ns}$ & $1663 * *$ \\
\hline $\mathrm{Y} \times \mathrm{C} \times \mathrm{M}$ & $27183 * *$ & $83.54 \mathrm{~ns}$ & $540562731 * *$ & $0.0000163 \mathrm{~ns}$ & $873 * *$ & $0.0035 \mathrm{~ns}$ & $1674 * *$ \\
\hline $\mathrm{Y} \times \mathrm{S} \times \mathrm{C} \times \mathrm{M}$ & $49184 * *$ & $62.354 \mathrm{~ns}$ & $22482861 * *$ & $0.0000150 \mathrm{~ns}$ & $96.5^{*}$ & $0.0093 \mathrm{~ns}$ & $680 *$ \\
\hline Error 2 & 3458 & 162 & 937562 & 0.000396 & 31.5 & 0.019 & 284 \\
\hline $\mathrm{CV}(\%)$ & 2.232 & 8.01 & 5.72 & 4.81 & 4.95 & 4.61 & 5.48 \\
\hline
\end{tabular}

Y: Years, S: Soil condition, C: Cultivars, M: Microorganisms.

$* * P<0.01, * P<0.05$, ns not significant. 

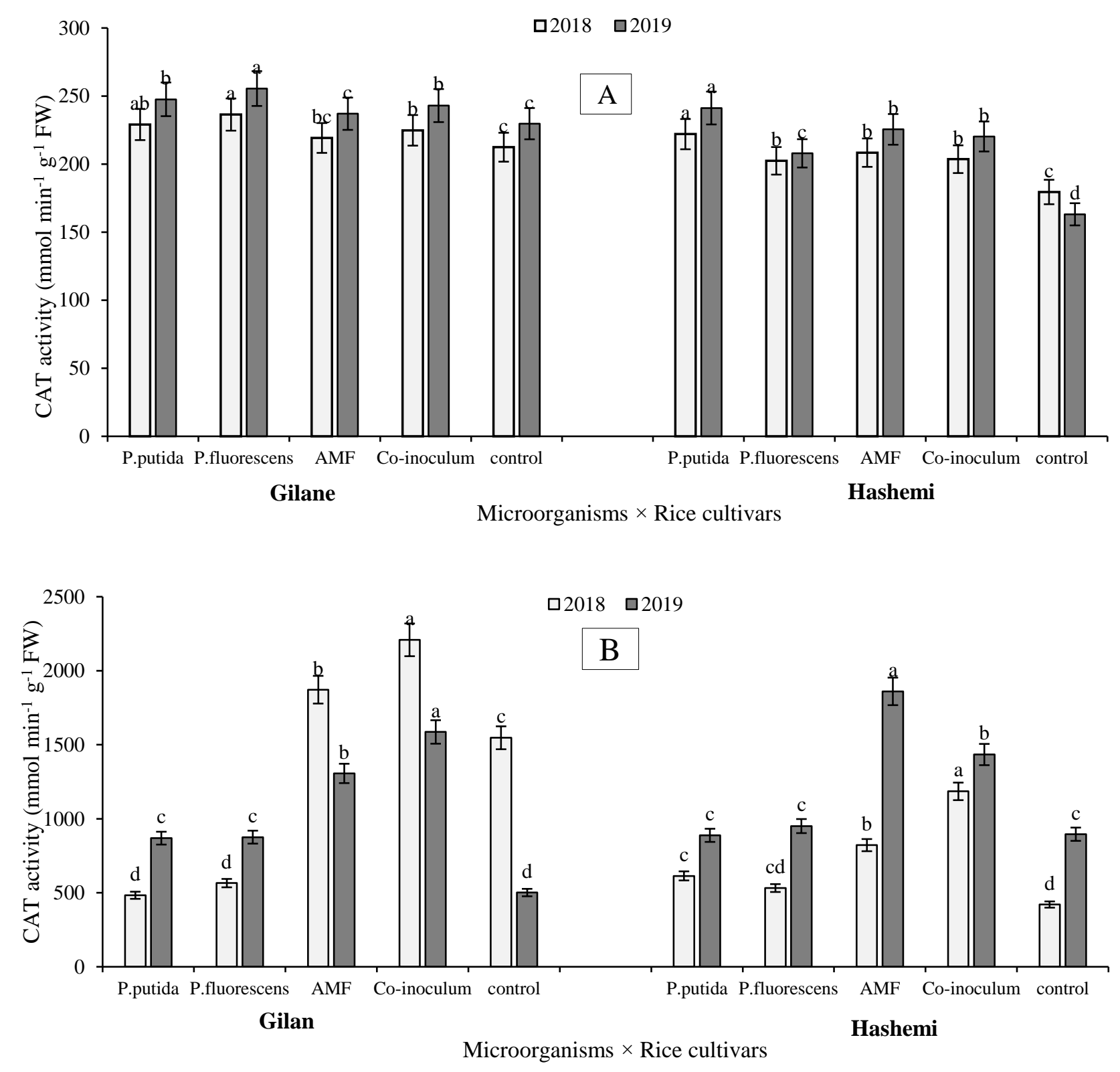

Figure 6. Mean comparison of interaction effect of cultivars $\times$ microorganisms on CAT activity in normal (A) and saline (B) soil.

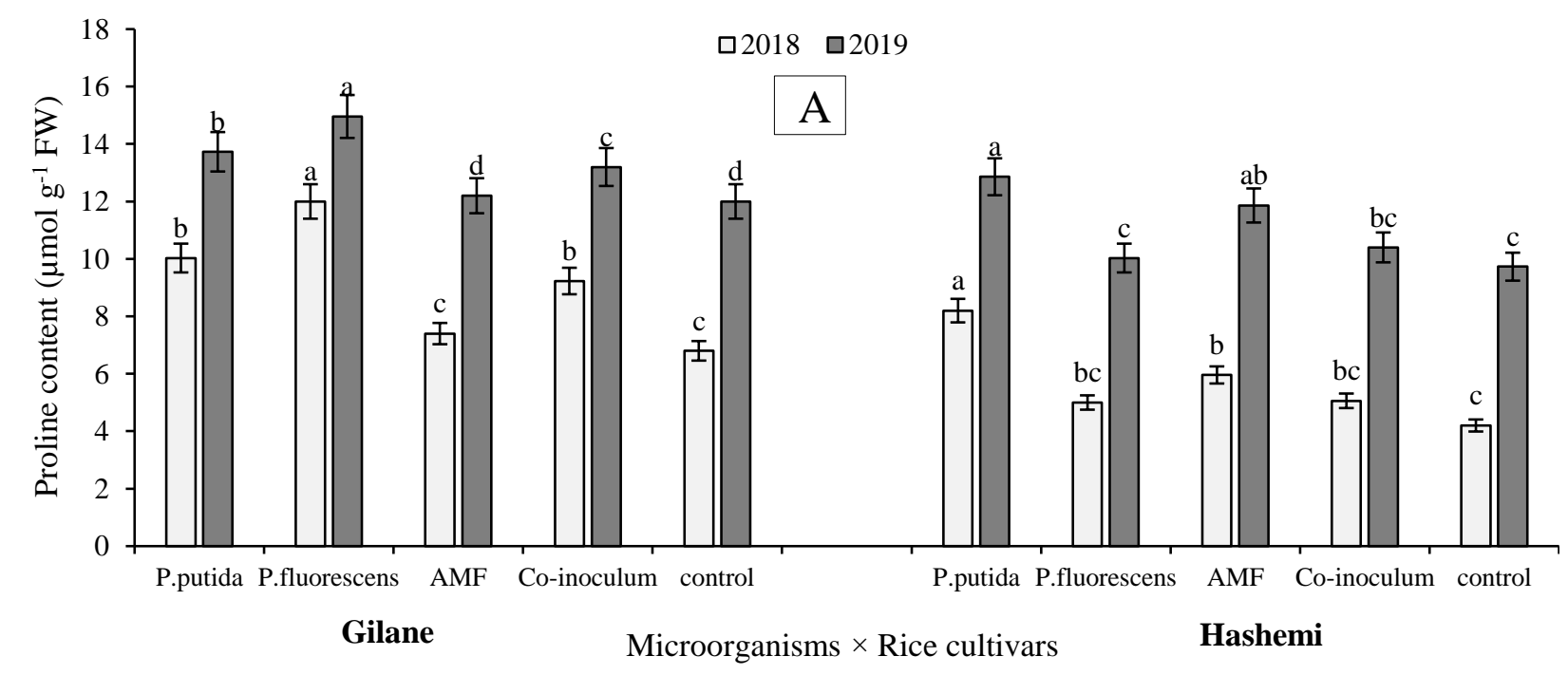




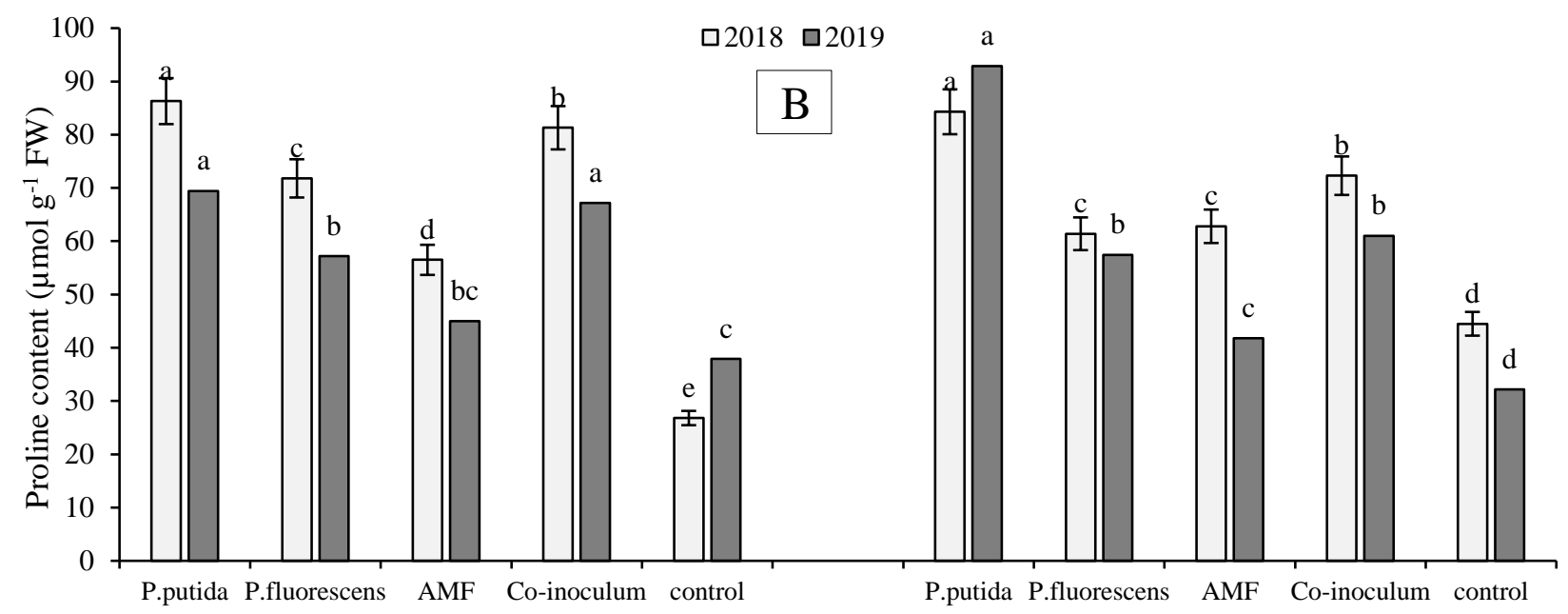

Gilane

Microorganisms $\times$ Rice cultivars

Hashemi

Figure 7. Mean comparison of interaction effect of cultivars $\times$ microorganisms on proline content in normal (A) and saline (B) soil.

\subsection{Leaf $N$ concentration}

Investigation of leaf nitrogen concentration revealed that soil condition $\times$ cultivars $\times$ microorganisms interaction was significant (Table 2). In both soil conditions, inoculated plants significantly resulted in higher leaf nitrogen concentration and this increment was $12-27 \%$ in normal soil (10-21\% in Hashemi and 14-27\% in Gilane) and 7-23\% in saline soil (12-23\% in Hashemi and $7-13 \%$ in Gilane). Although salinity remarkably decreased nitrogen concentration in all treatments but response of treatments especially pseudomonas species to cultivars and changes in soil conditions was different so that, ordering of inoculated treatments varied from normal to saline soil and from Guilneh to Hashemi cultivar (Figure 8).

\subsection{Plant height and stem diameter}

Results revealed that soil condition $x$ cultivars $x$ microorganisms interaction in both years was significant on plant height (Table 3 ). Soil salinity decreased this trait (8-17\% in first year and $11-24 \%$ in second year) but microorganisms increased this trait in normal soil (2.4$19 \%$ in first year and $6.9-52 \%$ in second year) and saline soil $(8.6-17.4 \%$ in first year and $11.9-28 \%$ in second year) than control. This increment was more obvious in saline soil. Although there was no significant difference among some microorganisms but higher height was seen in plants treated with mycorrhiza (AMF and coinoculated) (Table 4).

Opposed to plant height, stem diameter was not affected by microorganisms but soil condition $\times$ cultivars interaction effect was significant on stem diameter in both years (Table 3) so that, salinity decreased stem diameter in both cultivars and Gilane showed higher amount than Hashemi (Figure 9).

\subsection{Number of tiller}

In both years, soil condition $x$ cultivars $\times$ microorganisms interaction effect was significant on number of fertile tiller and also panicle (Table 3 ). In both years, salinity decreased number of fertile tiller but this decrease was lower in inoculated plants than control so that, inoculated plants in first year showed 3-22\% (Gilane with $12-22 \%$ and Hashemi with $4-19 \%$ ) and in second year showed $5-17 \%$ (Gilane with $6-17 \%$ and Hashemi with $5-14 \%$ ) increment than control. On the other hand, number of tiller per inoculate plants under normal soil conditions (except P.putida) was significantly higher than control (Table 5). Under normal soil conditions, although number of panicle per plants inoculated with Pseudomonas was higher than control but, the highest rate was observed in AMF inoculation $(2-19 \%$ in first year and $4-21 \%$ in second year). Superiority of inoculated plants under saline soil conditions to control plants was prominent so that, increase in number of panicles in inoculated plants as $14-31 \%$ in first year and $9-27 \%$ in second year was observed than control. In both cultivars, the highest rates of number of tiller and panicle were achieved in mycorrhizal treated (AMF and coinoculated) plants however, Hashemi better responded to inoculation than Gilane cultivar (Table 4).

\subsection{Filled grain number per panicle}

In both years, soil condition $x$ cultivars $\times$ microorganisms interaction effect was effective on filled grain number per plant (Table 3). By decreasing anthesis and increasing hollow grains, salinity resulted in decrease in grain number per panicle. Inoculation with microorganisms especially Pseudomonas-AMF increased grain number and inhibited hollow grains. The highest grain number in both soil conditions was achieved from 
co-inoculated plants so that, increase of 19 and $32 \%$ (first year) and 12 and 26\% (second year) in grain number under normal soil conditions was observed in Hashemi and Gilane cultivars, respectively. These rates under saline soil conditions included 24 and 47\% (first year) and 36 and $52 \%$ (second year) for Hashemi and Gilane cultivars, respectively. Although there was insignificant difference between AMF and co-inoculated plants under normal soil conditions but this difference was not significant under saline soil conditions. In fact, effect of AMF on grain number was superior to Pseudomonas species in saline soil (Table 5).

\subsection{Percent of unfilled grains}

Based on the results, soil condition $\times$ microorganisms interaction effect was significant on percent of unfilled grains (Table 3). Salinity remarkably increased percent of unfilled grains leading to grain yield loss. Although some inoculated treatments had no significant difference to control under normal soil conditions but significantly decreased percent of unfilled grains in saline soil (Figure 10).

\subsection{0 grain weight}

In both years, soil condition $\times$ cultivars $\times$ microorganisms interaction effect was significant on 1000 grain weight (Table 3). In Gilane cultivar, plants inoculated with microorganisms especially Pseudomonas species, showed more 1000 grain weight in both normal and saline soils but in first year, there was no significant difference between inoculated and control plants of Hashemi cultivar and in second year, inoculated plants except co-inoculated plants had superiority to control but in saline soil, AMF plants gained lower 1000 grain weight than control in both years although inoculated with Pseudomonas species showed higher 1000 grain weight (Table 5).

\subsection{Total biomass}

In both years, soil condition $\times$ cultivars $\times$ microorganisms interaction effect was significant on total biomass (Table 3). In both normal and saline soils, inoculated plants showed higher total biomass than control so that, in first year, under normal soil conditions this increment was $4-32 \%$ (4-15\% for Gilane) and 25$32 \%$ for Hashemi) and under saline soil conditions was 26-37\% (29-33\% for Gilane and 25-37\% for Hashemi). In second year, under normal soil conditions this increment was 5-23\% (4-15\% for Gilane) and 25-32\% for Hashemi) and under saline soil conditions was $29-61 \%$ (34-61\% for Gilane and $29-53 \%$ for Hashemi). Among the microorganisms, co-inoculated plants gained the highest biomass in both cultivars and P.putida had the lowest rate than the others (Table 5).

\subsection{Grain yield}

In both years, there were significant differences among treatments for grain yield, under normal and saline soil conditions (Table 3). However Hashemi cultivar gained higher grain yield than Gilane in both years and soil conditions but, salinity decreased grain yield of 55\% (first year) and 68\% (second year) from which, Gilane contributed to $67 \%$ (first year) and $45 \%$ (second year) amounts. These rates for Hashemi were $72 \%$ (first year) and 64\% (second year). In both years, microorganisms increased grain yield under both soil conditions and their impact was prominent under salinity conditions so that, increased grain yield in normal soil of $25-34 \%$ (first year) and 21-55\% (second year) and in saline soil of $22-45 \%$ (first year) and $45-67 \%$ (second year). The highest grain yield both in normal or saline soils was achieved from co-inoculated plants (Table 5).

\subsection{Harvest index}

Based on the results, soil condition $\times$ microorganisms interaction effect was significant on harvest index (Table 3). Salinity decreased assimilates remobilization from different parts to the grains. In normal soil, Pseudomonas species decreased harvest index than control but AMF and co-inoculated plants showed significant superiority to control while in normal soil, treatments except P.putida significantly increased harvest index than control (Figure 11).

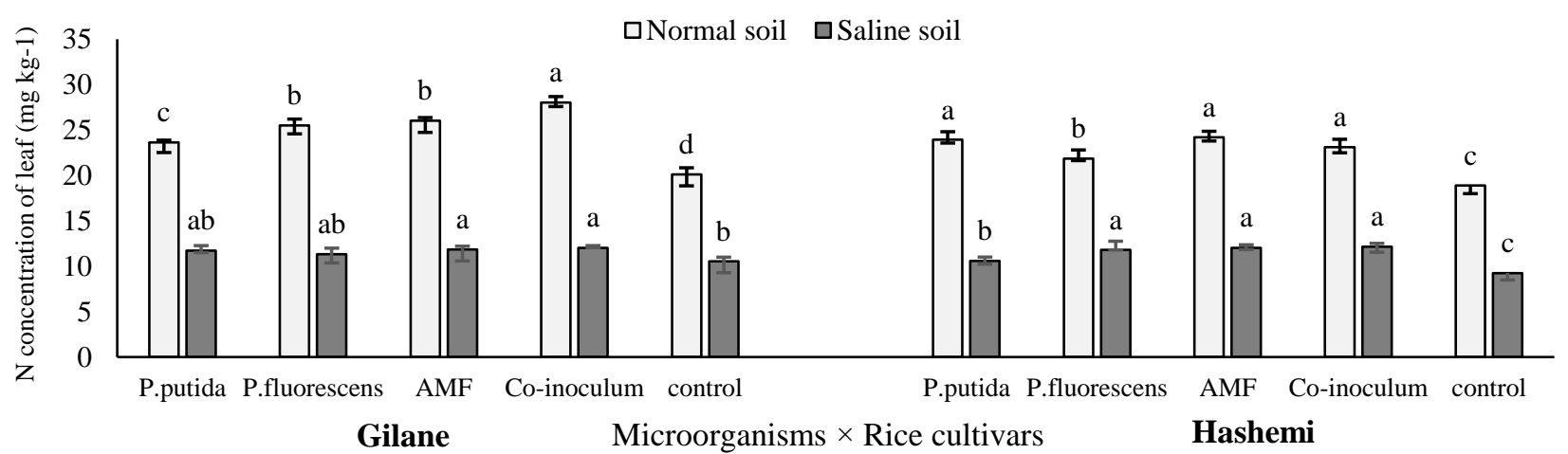

Figure 8. Mean comparison of interaction effect of cultivar $\times$ microorganism $\times$ soil conditions on $\mathrm{N}$ concentration. 


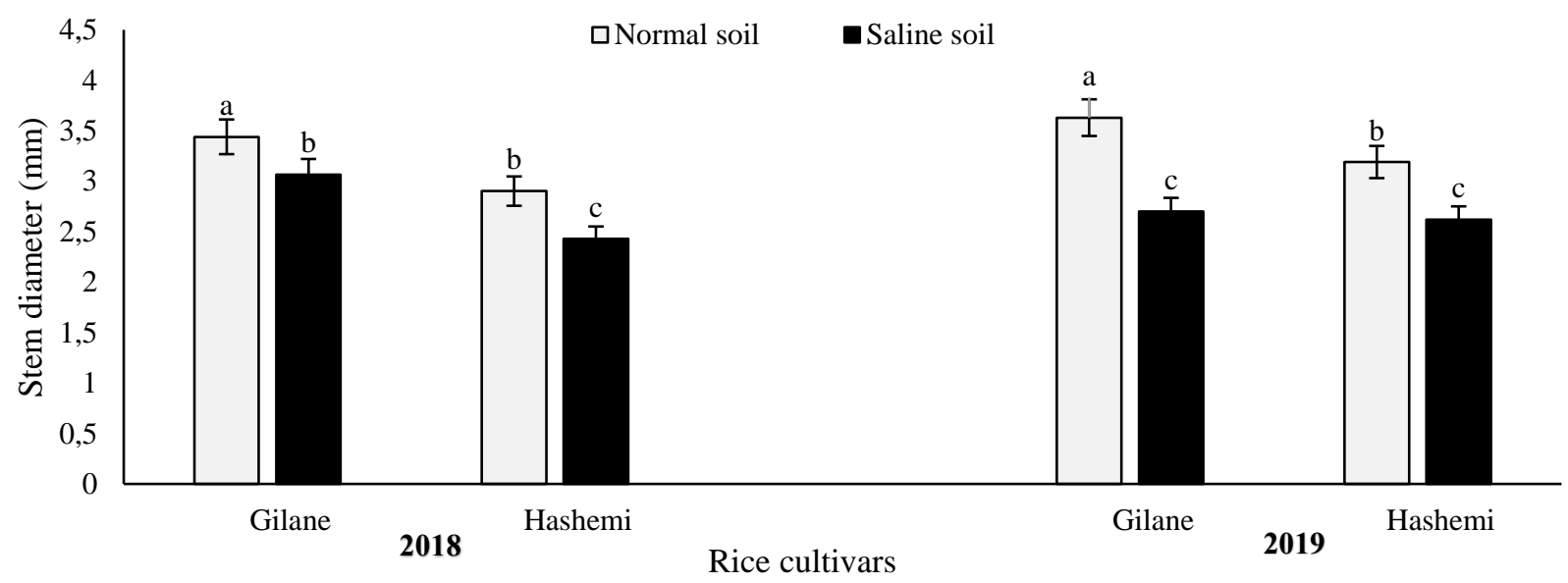

Figure 9. Mean comparison of interaction effect of soil condition $\times$ cultivars on stem diameter.

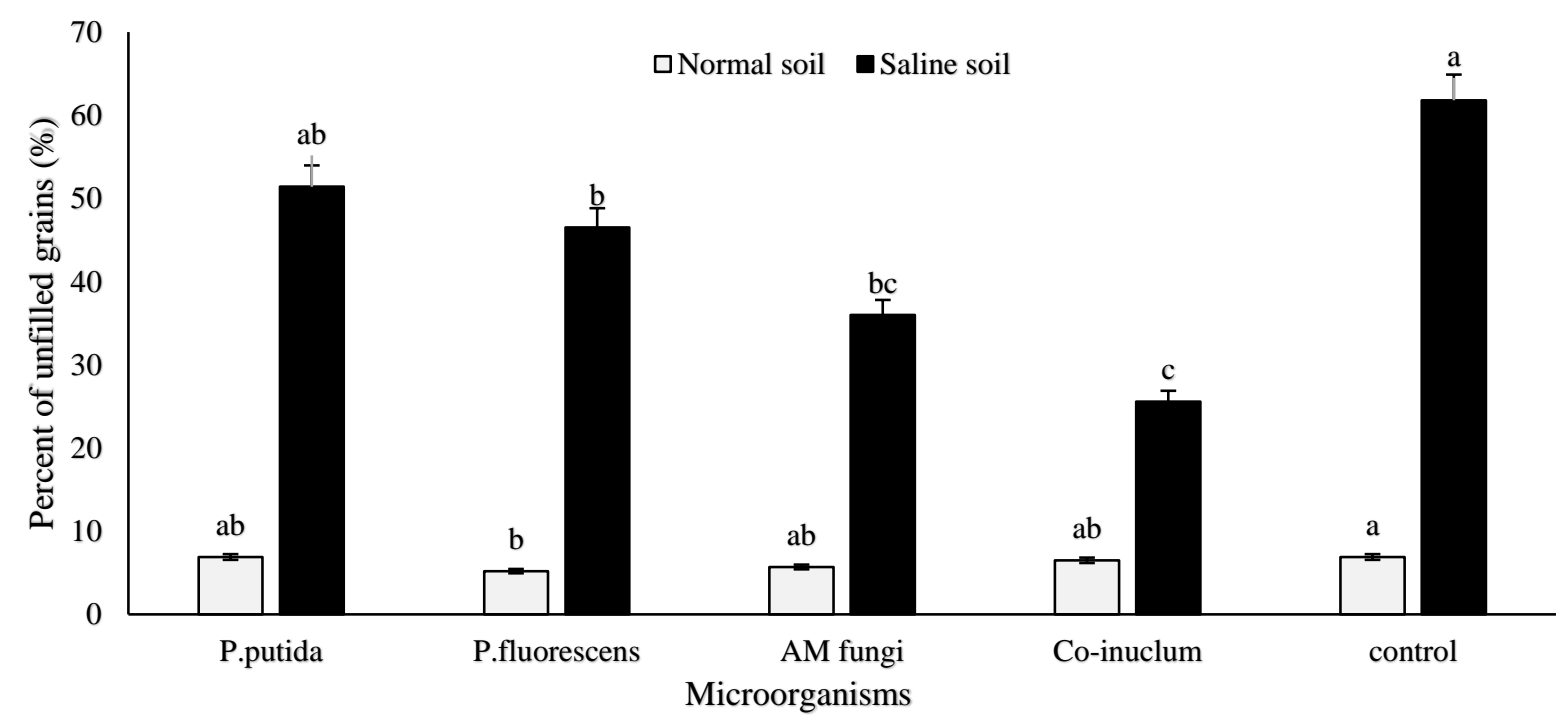

Figure 10. Mean comparison of soil condition $\times$ microorganisms effect on percent of unfilled grains.

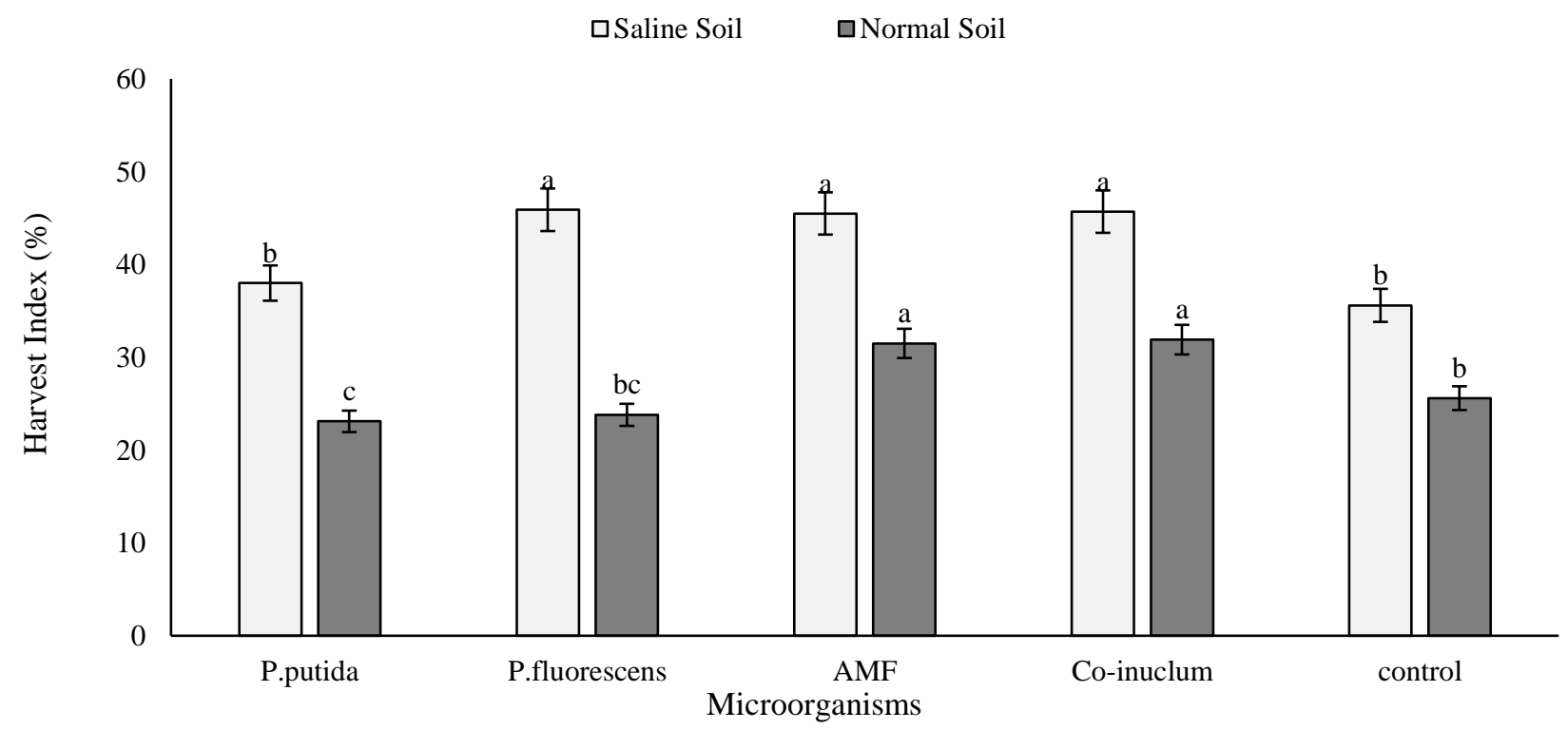

Figure 11. Mean comparison of soil condition $\times$ microorganisms effect on percent unfilled grains. 
Table 3. Analysis of variance of microorganisms $\times$ soil condition effect on agronomic traits of rice cultivars in 2018 and 2019.

\begin{tabular}{|c|c|c|c|c|c|c|c|}
\hline \multirow[b]{2}{*}{ S.O.V } & \multicolumn{6}{|c|}{ MS (Mean Square) } & \multirow[b]{2}{*}{$\begin{array}{c}\text { Harvest } \\
\text { index }\end{array}$} \\
\hline & $\begin{array}{l}\text { Panicle } \\
\text { number }\end{array}$ & $\begin{array}{l}\text { Filled grain } \\
\text { number }\end{array}$ & $\begin{array}{c}\text { Percent of } \\
\text { unfilled grains }\end{array}$ & $\begin{array}{l}1000 \text { - grain } \\
\text { weight }\end{array}$ & $\begin{array}{l}\text { Grain } \\
\text { yield }\end{array}$ & $\begin{array}{c}\text { Total } \\
\text { biomass }\end{array}$ & \\
\hline $\bar{Y}$ & $12.1 * *$ & $38.1 \mathrm{~ns}$ & $11.5 \mathrm{~ns}$ & $0.561 \mathrm{~ns}$ & $8093 \mathrm{~ns}$ & $91885 \mathrm{~ns}$ & $3.32 \mathrm{~ns}$ \\
\hline S & $23.06 * *$ & $1101 * *$ & $77.7 * *$ & $99.3 * *$ & $553776 * *$ & $80041500 * *$ & $12.32 * *$ \\
\hline Error 1 & 0.117 & 26.8 & 7.22 & 0.768 & 7645 & 142637 & 1.016 \\
\hline $\mathrm{C}$ & $0.010 \mathrm{~ns}$ & $640 * *$ & $1.3 \mathrm{~ns}$ & $81.3 * *$ & $4663348 * *$ & $433500 \mathrm{~ns}$ & $5.073 \mathrm{~ns}$ \\
\hline M & $0.375 \mathrm{~ns}$ & $310 * *$ & $67.2 * *$ & $4.36^{* *}$ & 621839. ** & $2651416 * *$ & $31.7 * *$ \\
\hline $\mathrm{S} \times \mathrm{Y}$ & $1.410^{* *}$ & $79.3 \mathrm{~ns}$ & $3.84 \mathrm{~ns}$ & $2.67 * *$ & $2278088^{* *}$ & $13537500^{* *}$ & $0.730 \mathrm{~ns}$ \\
\hline $\mathrm{C} \times \mathrm{Y}$ & $1.94 * *$ & $211 * *$ & $2.85 \mathrm{~ns}$ & $0.590 \mathrm{~ns}$ & $1489980 * *$ & $1631916 * *$ & $0.540 \mathrm{~ns}$ \\
\hline$M \times Y$ & $0.227 \mathrm{~ns}$ & $425^{* *}$ & $4.17 \mathrm{~ns}$ & $1.846^{* *}$ & $280401 * *$ & $888916^{* *}$ & $1.7 \mathrm{~ns}$ \\
\hline $\mathrm{S} \times \mathrm{C}$ & $1.156^{* *}$ & $284 * *$ & $5.8 \mathrm{~ns}$ & $2.93 * *$ & $326330 * *$ & $577083 * *$ & $8.60 \mathrm{~ns}$ \\
\hline $\mathrm{S} \times \mathrm{M}$ & $0.104 \mathrm{~ns}$ & $285^{* *}$ & $65.0 * *$ & $42.5^{* *}$ & $12326^{*}$ & $2417632 * *$ & $22.7 * *$ \\
\hline $\mathrm{C} \times \mathrm{M}$ & $0.651 \mathrm{~ns}$ & $1036 * *$ & $2.80 \mathrm{~ns}$ & $3.05^{* *}$ & $1647265^{* *}$ & $6723235^{* *}$ & $5.22 \mathrm{~ns}$ \\
\hline $\mathrm{M} \times \mathrm{C} \times \mathrm{S}$ & $3.956 * *$ & $24.3 \mathrm{~ns}$ & $4.62 \mathrm{~ns}$ & $3.12 * *$ & $64920051^{* *}$ & $39569343 * *$ & $0.941 \mathrm{~ns}$ \\
\hline $\mathrm{Y} \times \mathrm{S} \times \mathrm{C}$ & $0.028 \mathrm{~ns}$ & $912 * *$ & $2.56 \mathrm{~ns}$ & $10.8 * *$ & $1636801 * *$ & $14061168 * *$ & $0.066 \mathrm{~ns}$ \\
\hline $\mathrm{Y} \times \mathrm{S} \times \mathrm{M}$ & $0.419 \mathrm{~ns}$ & $269 * *$ & $4.13 \mathrm{~ns}$ & $15.6^{* *}$ & $533311 * *$ & $4050073 * *$ & $1.19 \mathrm{~ns}$ \\
\hline $\mathrm{Y} \times \mathrm{C} \times \mathrm{M}$ & $0.366 \mathrm{~ns}$ & $815^{* *}$ & $2.26 \mathrm{~ns}$ & $2.59 * *$ & $991992 * *$ & $7654504 * *$ & $0.360 \mathrm{~ns}$ \\
\hline $\mathrm{Y} \times \mathrm{S} \times \mathrm{C} \times \mathrm{M}$ & $0.925^{* *}$ & $433^{* *}$ & $3.6 \mathrm{~ns}$ & $12.4^{* *}$ & $22590 * *$ & $638059 *$ & $1.108 \mathrm{~ns}$ \\
\hline Error 2 & 0.185 & 21.5 & 3.49 & 0.592 & 4318 & 227513 & 2.73 \\
\hline$\overline{\mathrm{CV}(\%)}$ & 7.08 & 5.59 & 9.17 & 3.72 & 2.36 & 6.32 & 4.5 \\
\hline
\end{tabular}

Y: Year, S: Soil condition, C: Cultivars, M: Microorganisms.

** $P<0.01, * P<0.05$, ns not significant.

Table 4. Mean comparison of soil condition $\times$ microorganisms effect on agronomic traits of rice cultivars in 2018 and 2019

\begin{tabular}{|c|c|c|c|c|c|c|c|c|c|}
\hline \multirow[t]{2}{*}{ Cultivars } & \multirow[t]{2}{*}{ Microorganisms } & \multicolumn{2}{|c|}{$\begin{array}{c}\text { Plant } \\
\text { height }(\mathrm{cm})\end{array}$} & \multicolumn{2}{|c|}{$\begin{array}{l}\text { Fertile tiller } \\
\text { number } \mathrm{m}^{-2}\end{array}$} & \multicolumn{2}{|c|}{$\begin{array}{l}\text { Panicle number } \\
\text { plant }^{-1}\end{array}$} & \multicolumn{2}{|c|}{$\begin{array}{c}\text { Filled grain } \\
\text { number panicle }\end{array}$} \\
\hline & & 2018 & 2019 & 2018 & 2019 & 2018 & 2019 & 2018 & 2019 \\
\hline & & & \multicolumn{7}{|c|}{ Normal soil } \\
\hline \multirow{5}{*}{ Gilane } & P.putida & $106 \mathrm{e}$ & $109 \mathrm{ef}$ & $280 \mathrm{~g}$ & $310 \mathrm{bc}$ & $6.33 \mathrm{bcd}$ & $6.8 \mathrm{abc}$ & $76.7 \mathrm{e}$ & 92.0de \\
\hline & P.fluorescens & $116 \mathrm{~d}$ & $111 \mathrm{ef}$ & $285 f g$ & $315 b c$ & $6.20 \mathrm{~cd}$ & $6.73 b c$ & $74.1 \mathrm{e}$ & $98.7 \mathrm{~cd}$ \\
\hline & AMF & $107 \mathrm{e}$ & 114def & $316 \mathrm{~d}$ & $323 a b$ & $6.93 \mathrm{abc}$ & $7.26 \mathrm{ab}$ & $78.3 \mathrm{de}$ & $99.0 \mathrm{~cd}$ \\
\hline & Co-inoculum & $117 d$ & $117 \mathrm{cde}$ & 306de & $338 \mathrm{a}$ & $6.50 \mathrm{bcd}$ & $7.00 \mathrm{abc}$ & $82.5 d$ & $98.7 \mathrm{~cd}$ \\
\hline & control & $103 \mathrm{e}$ & 104.f & $260 \mathrm{~h}$ & $300 c$ & $6.10 \mathrm{~d}$ & $6.53 \mathrm{c}$ & $67.6 \mathrm{f}$ & $87.3 \mathrm{e}$ \\
\hline \multirow{6}{*}{ Hashemi } & P.putida & $139 b$ & $123 b c$ & $374 a$ & $315 b c$ & $6.80 \mathrm{bcd}$ & $7.26 \mathrm{ab}$ & $98.9 \mathrm{c}$ & $103 b c$ \\
\hline & P.fluorescens & $134 b c$ & $124 b c$ & $344 b$ & $315 b c$ & $6.86 \mathrm{bcd}$ & 7.40ab & $104.5 b c$ & 104.bc \\
\hline & AMF & $138 b$ & $130 \mathrm{~b}$ & $331 \mathrm{c}$ & $315 b c$ & 7.00ab & $7.50 \mathrm{a}$ & $104.8 b$ & $110 \mathrm{~b}$ \\
\hline & Co-inoculum & $148 \mathrm{a}$ & $136 \mathrm{a}$ & $283 f g$ & $325 \mathrm{ab}$ & $7.66 \mathrm{a}$ & $7.50 \mathrm{a}$ & $110.6 \mathrm{a}$ & $123 a$ \\
\hline & control & 132.c & $115 \mathrm{def}$ & 294ef & $280 \mathrm{~d}$ & $6.46 \mathrm{bcd}$ & $6.76 \mathrm{bc}$ & $75.3 \mathrm{e}$ & $92.3 \mathrm{de}$ \\
\hline & & & \multicolumn{7}{|c|}{ Saline soil } \\
\hline \multirow{5}{*}{ Gilan } & P.putida & $99.0 \mathrm{c}$ & $95.6 \mathrm{~cd}$ & $233 b c$ & $250 \mathrm{ab}$ & 5.40ab & $4.700 \mathrm{~cd}$ & $47.8 \mathrm{e}$ & $50.10 \mathrm{~d}$ \\
\hline & P.fluorescens & $108 . b$ & $99.6 \mathrm{bcd}$ & $254 \mathrm{ab}$ & $270 \mathrm{a}$ & $5.53 \mathrm{ab}$ & $4.666 \mathrm{~cd}$ & $60.4 \mathrm{~cd}$ & $49.20 \mathrm{~d}$ \\
\hline & AMF & $96.0 \mathrm{c}$ & $98.0 \mathrm{bcd}$ & $257 \mathrm{ab}$ & $278 \mathrm{a}$ & $5.60 \mathrm{ab}$ & $4.733 \mathrm{~cd}$ & $51.6 \mathrm{de}$ & $54.76 \mathrm{~d}$ \\
\hline & Co-inoculum & $101 b c$ & $104.6 a b c$ & $264 a$ & $281 \mathrm{a}$ & $5.73 \mathrm{a}$ & $5.166 b c$ & $62.3 \mathrm{~cd}$ & $74.40 \mathrm{c}$ \\
\hline & Control & $93.3 \mathrm{c}$ & $79.3 \mathrm{e}$ & $227 \mathrm{~cd}$ & $220 \mathrm{c}$ & $4.93 b c$ & $4.300 \mathrm{~d}$ & $33.2 \mathrm{f}$ & $36.50 \mathrm{e}$ \\
\hline \multirow{5}{*}{ Hashem } & P.putida & $93.3 \mathrm{c}$ & $105.4 \mathrm{ab}$ & $207 d$ & $215 c$ & $5.33 \mathrm{abc}$ & $5.266 \mathrm{abc}$ & $63.6 \mathrm{bcd}$ & $75.56 \mathrm{~b}$ \\
\hline & P.fluorescens & $96.0 \mathrm{c}$ & 104.0abc & $234 b c$ & $235 b c$ & $5.66 \mathrm{ab}$ & $5.300 \mathrm{abc}$ & 71.9ab & $81.46 \mathrm{a}$ \\
\hline & $\mathrm{AMF}$ & 108.b & $106.333 \mathrm{ab}$ & $239 b c$ & $264 a$ & $5.80 \mathrm{a}$ & $5.533 \mathrm{ab}$ & $75.4 \mathrm{a}$ & $86.70 \mathrm{a}$ \\
\hline & Co-inoculum & $112 \mathrm{a}$ & $109.3 \mathrm{a}$ & $260 \mathrm{~b}$ & $255 \mathrm{a}$ & $5.86 \mathrm{a}$ & $5.933 \mathrm{a}$ & $76.3 \mathrm{a}$ & $85.83 a$ \\
\hline & Control & $99.0 \mathrm{c}$ & $93.3 \mathrm{~d}$ & 199d & $211 \mathrm{c}$ & $4.60 \mathrm{c}$ & $5.066 \mathrm{bc}$ & $59.9 d$ & $55.93 d$ \\
\hline
\end{tabular}

Means followed by the same letter are not significantly different $(P<0.05)$ as determined by Least Significant Difference (LSD) test. 
Table 5. Mean comparison of soil condition $\times$ microorganisms effect on agronomic traits of rice cultivars in 2018 and 2019.

\begin{tabular}{|c|c|c|c|c|c|c|c|}
\hline \multirow{2}{*}{ Cultivars } & \multirow{2}{*}{ Microorganisms } & \multicolumn{2}{|c|}{1000 - grain weight $(\mathrm{g})$} & \multicolumn{2}{|c|}{ Total biomass $\left(\mathrm{t} \mathrm{hm}^{-2}\right)$} & \multicolumn{2}{|c|}{ Grain yield $\left(\mathrm{t} \mathrm{hm}^{-2}\right)$} \\
\hline & & 2018 & 2019 & 2018 & 2019 & 2018 & 2019 \\
\hline & \multicolumn{7}{|c|}{ Normal soil } \\
\hline \multirow{5}{*}{ Gilane } & P.putida & $28.1 \mathrm{a}$ & $27.46 a$ & $10507 \mathrm{e}$ & $9920 b c$ & $3385 \mathrm{e}$ & $3436 f$ \\
\hline & P.fluorescens & $27.8 \mathrm{a}$ & $26.35 \mathrm{ab}$ & 10734de & $10437 b c$ & 3800de & $5530 \mathrm{~cd}$ \\
\hline & AMF & $26.5 b$ & $24.5 \mathrm{~cd}$ & $11233 \mathrm{~cd}$ & $9952 b c$ & 4634abcd & $5728 \mathrm{bc}$ \\
\hline & Co-inoculum & $26.7 \mathrm{ab}$ & $23.8 \mathrm{cde}$ & $11915 b$ & $10665 b$ & $4890 \mathrm{abc}$ & $5892 \mathrm{bc}$ \\
\hline & control & $26.4 b$ & $25.0 \mathrm{bc}$ & $9833 \mathrm{f}$ & $8601 d$ & $2176 f$ & $3274 f$ \\
\hline \multirow{6}{*}{ Hashemi } & P.putida & $24.8 \mathrm{c}$ & $23.9 \mathrm{cde}$ & $11424 b c$ & $9958 b c$ & $4434 \mathrm{bcd}$ & $5023 d$ \\
\hline & P.fluorescens & $24.6 \mathrm{c}$ & 23.61de & $11509 \mathrm{bc}$ & $10439 b c$ & $5053 \mathrm{ab}$ & $6199 \mathrm{ab}$ \\
\hline & AMF & $24.5 \mathrm{c}$ & $22.9 \mathrm{e}$ & $12133 b$ & $12060 \mathrm{a}$ & $5379 \mathrm{ab}$ & $6285 \mathrm{ab}$ \\
\hline & Co-inoculum & $24.2 \mathrm{c}$ & $21.39 \mathrm{f}$ & $13207 \mathrm{a}$ & $12172 \mathrm{a}$ & $5578 \mathrm{a}$ & $6582 \mathrm{a}$ \\
\hline & control & $23.6 \mathrm{c}$ & $21.60 \mathrm{f}$ & $10210 \mathrm{e}$ & $9456 \mathrm{~cd}$ & 3991cde & $4163 e$ \\
\hline & \multicolumn{7}{|c|}{ Saline soil } \\
\hline \multirow{5}{*}{ Gilan } & P.putida & $24.00 \mathrm{a}$ & $22.9 \mathrm{ab}$ & $4233 d$ & $4566 \mathrm{~d}$ & $629 \mathrm{~h}$ & $585 \mathrm{~g}$ \\
\hline & P.fluorescens & $23.1 \mathrm{ab}$ & $23.5 \mathrm{a}$ & $4346 \mathrm{~d}$ & $4643 d$ & $1002 \mathrm{~g}$ & $1039 f$ \\
\hline & AMF & $23.6 \mathrm{ab}$ & $21.3 \mathrm{~cd}$ & $4924 b c$ & $3819 \mathrm{e}$ & $1282 \mathrm{ef}$ & $1424 d$ \\
\hline & Co-inoculum & $22.1 \mathrm{~cd}$ & $21.9 \mathrm{bc}$ & $5057 \mathrm{bc}$ & $6076 c$ & $1468 d$ & $1791 \mathrm{c}$ \\
\hline & control & $22.6 b c$ & $20.4 \mathrm{de}$ & $2756 \mathrm{e}$ & $2485 \mathrm{~g}$ & $595 \mathrm{i}$ & $294 \mathrm{~h}$ \\
\hline \multirow{5}{*}{ Hashem } & P.putida & $23.4 \mathrm{ab}$ & $21.4 \mathrm{~cd}$ & $5065 \mathrm{bc}$ & $3870 \mathrm{e}$ & $1502 \mathrm{de}$ & $1107 \mathrm{e}$ \\
\hline & P.fluorescens & $21.3 \mathrm{de}$ & $21.0 \mathrm{~cd}$ & $5433 \mathrm{ab}$ & $6378 b$ & $1768 \mathrm{c}$ & $1048 \mathrm{e}$ \\
\hline & $\mathrm{AMF}$ & $20.7 \mathrm{ef}$ & 19.1ef & $5829 a$ & $5885 \mathrm{c}$ & $1916 b$ & $1764 b$ \\
\hline & Co-inoculum & $19.7 \mathrm{f}$ & $18.9 \mathrm{f}$ & $5748 \mathrm{a}$ & $6665 a$ & $2213 a$ & $2138 \mathrm{a}$ \\
\hline & control & $20.8 \mathrm{e}$ & $20.3 \mathrm{de}$ & $3433 d$ & $2741 f$ & $1213 \mathrm{f}$ & $923 \mathrm{~g}$ \\
\hline
\end{tabular}

Means followed by the same letter are not significantly different $(P<0.05)$ as determined by Least Significant Difference (LSD) test.

In this study, soil salinity decreased growth and yield of rice cultivars in both years which is due to inhibitive impact of salinity such as photosynthesis, water and nutrient elements uptake which in turn, inhibits growth and cell division (Grattan and Grieve, 1999; Hasegawa et al., 2000; Tofighi et al., 2017). Decrease in synthesis of photosynthetic pigments (chlorophyll a, chlorophyll b, and carotenoids) is one of the important impacts of salinity leading to decrease in photosynthetic capacity (Jogawat et al., 2013; Campanelli et al., 2013; Porcel et al., 2015). In our work, under normal soil conditions, chlorophyll increment lasted to panicle differentiation stage but soil salinity decreased leaf chlorophyll content of both cultivars after maximum tillering stage and it lasted until soft dough, but inoculated plants inhibited intensity of chlorophyll loss and improved its synthesis.

Under both soil conditions, inoculated plants showed higher chlorophyll content than control and in saline soil, co-inoculated plants contained higher rates than the other treatments. This is in accordance with findings of Jha and Subramanian (2015), Tofighi et al. (2017), and Bhambure et al. (2018). Zhu et al. (2014), attributed increase in chlorophyll content of inoculated plants to increase in minerals uptake especially phosphorous and manganese. Jha and Subramanian (2013) and Porcel et al. (2015) revealed that PGPR (Plant Growth Promoting Rhizobacteria) and AMF rice plants possessed higher Rubisco activity under salinity conditions and impact of these microorganisms on lower metabolic limitations of photosynthesis than control plants has been revealed (Evelin et al., 2009; Neto et al., 2014; Chen et al., 2014). Rubisco activity highly is correlated with $\mathrm{CO}_{2}$ assimilation (Evelin et al., 2013). Same to our results, Porcel et al. (2016) and Yan et al. (2015) found that increase in photosynthetic activity and growth in rice inoculated with AMF and PGPR (plant growth promoting rhizobacteria) may be due to non-stomatal factors like increase in chlorophyll a content and Rubisco activity.

On the other hand, salinity limits atmospheric $\mathrm{CO}_{2}$ absorption by stomata closure and decreases NADPH consumption by Calvin cycle (Levine et al., 1994) and induces synthesis of the oxidative metabolism products such as single oxygen $\left({ }^{1} \mathrm{O}_{2}\right)$, Superoxide radicals $\left(\mathrm{O}_{2}{ }^{\circ-}\right)$, hydroxyl radicals $\left(\mathrm{OH}^{\circ}\right)$ and $\mathrm{H}_{2} \mathrm{O}_{2}$ (Levine et al., 1994; Lee et al., 2001; Miller et al., 2010). In our research, inoculated plants especially co-inoculated ones and AMF significantly decreased Leaf $\mathrm{H}_{2} \mathrm{O}_{2}$ content than control however, in absence of the salinity, no prominent difference was observed between inoculated plants and control. In this work, it was revealed that in normal soil, inoculated plants possessed higher activity of catalase (CAT) than control (6-31\% in first year and $9-47 \%$ in second year) and the highest activities in Gilane and Hashemi cultivars were achieved from plants inoculated with P.fluorescens and P.putida while plants inoculated 
with Pseudomonas species showed insignificant difference with control under salinity conditions and the highest CAT activities were observed in AMF and coinoculated plants so that, these treatments increased CAT activity in Gilane of $17-30 \%$ (first year) and $62-68 \%$ (second year), and in Hashemi of 45-65\% (first year) and $45-57 \%$ (second year) than control.

Results of the present work support the findings of the past studies reporting the increase in antioxidant enzymatic activity by AMF (Fernández et al., 2011; Porcel et al., 2015) and P. pseudoalcaligenes (Bal et al., 2013) inoculation, in response to salinity stress. Han and Lee (2005) and Jha and Subramanian (2013) reported that induction of antioxidant enzymes like CAT, POD, and SOD synthesized by growth promoting microorganisms may be considered as a salt-tolerant mechanism in paddy plants which are involved in eliminating $\mathrm{H} 2 \mathrm{O} 2$ from saltstressed plants. Also, Alguacil et al. (2003) and Evelin et al. (2009) reported that AMF symbiosis inducing activities of several antioxidant enzymes may be the indirect result of the AMF effects on host plant growth and acquisition of $\mathrm{P}$ or $\mathrm{N}$. However, there exist various reports about affecting pathways of AMF and Pseudomonas species on antioxidative enzyme activity of rice under salinity stress which could be due to the diversity of the microorganisms, soil conditions, type of environmental stress and plant cultivar (Parvin et al., 2019; Yasmeen et al., 2019).

One of the other impacts of PGPR and AM, especially bacteria with the potential of ACC deaminase synthesis is to produce secondary metabolites like proline, under drought and salinity which is in accordance with findings of this work demonstrating increase in the proline synthesis from $7.3 \mu \mathrm{mol} \mathrm{g} \mathrm{g}^{-1} \mathrm{FW}$ to $61.6 \mu \mathrm{mol} \mathrm{g}{ }^{-1} \mathrm{FW}$ under salinity conditions and superiority of the most treatments to control in both years and cultivars. In normal soil, the highest leaf proline contents of Gilane and Hashemi cultivars were obtained from P.fluorescens and P.putida, respectively, but in saline soil and both cultivars, the highest rates were observed in plants inoculated with P.putida followed by co-inoculated plants.

Proline is an $\mathrm{N}$ containing compound; therefore, increased $\mathrm{N}$ uptake by plants leads to raised proline biosynthesis, which results in increased proline content in plants (Campanelli et al., 2013). Comparison of mean data on protein content of flag leaf demonstrated that under normal and saline soil conditions, the inoculated treatments had significant effects on protein content. Salinity stress changed some metabolism pathways in addition to reducing plant growth and development (Demirevska et al., 2008; Ahmadpour et al., 2016). These changes can make plants resistant to stress (Bian and Jiang, 2008). During dehydration, intense and prolonged stress caused by reduced water availability increases the compatible osmolites inside the cells, which increases osmotic potential (Bian and Jiang, 2008). Expression of a series of proteins increases under abiotic stress conditions such as drought, salinity, heat, and cold. These proteins play a role in plant adjustment to stress conditions. Moreover, they have an important role in osmotic adjustment by plants under conditions of drought and salinity (Ahmadpour et al., 2016). The soluble proteins are as follows: dehydrins, synthesis enzymes of metabolites and heat-shock proteins (Hsps) (Demirevska et al., 2008). Accumulation of solutes such as proline and soluble protein, leads to reduction of cells osmotic potential therefore, plays an important role in increasing the uptake of water from the soil and maintain turgor pressure (Rahbarian et al., 2011).

Resulted findings of this work suggest that one of the reasons for decreasing leaf $\mathrm{N}$ concentration under salinity conditions is synthesis of proline and other compatible osmolite, in addition to limitations in $\mathrm{N}$ uptake. In other words, synthesis of these compounds is costly for plant and these elements and synthesized compounds are used for increasing salt stress tolerance rather than plant growth and thus, decrease yield so, both AMF and Pseudomonas treatments independently as well as their interactions which may improve growth and tolerance by enhancing nutrient availability, water uptake and hydraulic conductivity which leads to metabolic changes including increased protein biosynthesis that decreases growth inhibition under salt stress (Mathur and Vyas, 2000; Evelin et al., 2009; Campanelli et al., 2013).

Nitrogenous heterocycles are the raw materials required for protein biosynthesis so an increase in protein content in leaves is directly related to an increase of nitrogen uptake by the plants (Atik, 2013; Hosseinzadeh et al., 2017).

Soil salinity decreased plant height of both cultivars in first and second years, of about $8-17 \%$ and $11-24 \%$ than normal conditions but inoculation under normal conditions (2.4-19\% in first year and 6.9-52\% in second year) and saline conditions (8.6-17.4\% in first year and $11.9-28 \%$ in second year) increased plant height than control. The highest plant height in both cultivars was observed in AMF and co-inoculated plants. Based on the findings of RuizLozano et al. (2012), during the salt stress, AMF symbiosis exerts vast morphologic changes in rice that provides it for salt tolerance and the majority of these changes these changes concern vacuolar or cytoplasmic membrane systems. Ansari et al. (2018) reported that under drought stress, plants with higher heights may increase final grain weight and yield during the grain filling by remobilization process. On the other hands, rice grain yield is a function of different components like fertile tiller number, panicle number, grain number and grain weight so, impact of treatments on grain yield is defined by impacting on yield components. 
Number of fertile tillers and panicles under both soil conditions were increased as a result of inoculations except P.putida. Increase in number of tiller and panicle was observed in co-inoculated plants however, not significant difference with AMF plants was observed in some conditions. Increase in number of tiller, panicle and grain in plants inoculated with AMF under salt stress has been reported in wheat (Fernández et al., 2011; Pellegrino et al., 2012; Zhang et al., 2015) and in wheat (Talaat and Shawky, 2011). Increase in these components impact on grain yield in rice which is in accordance with our findings. The reason for increase in grain components of AMF plants may be attributed to increase in macronutrients uptake like N (Ansari et al., 2018), P (Daei et al., 2009) and K (Halder et al., 2015) especially in saline soil. Furthermore, AMF symbiosis alters rates of water flow in, through and out of plant (Bárzana et al., 2012; Jha and Subramanian, 2013) and its impact on improving root hydraulic conductivity, stomatal conductivity, and rate of gas exchange has been confirmed (Augé, 2004; Ruiz-Lozano et al., 2012; Bárzana et al., 2014). Krajinski et al. (2000) believe that under salt stress, Glomus deserticola impacts on genes encoding membraneassociated proteins like aquaporin's. Importance of all exerted treatments in rice grain yield and total biomass is distinguished under normal and saline soils.

In both years, inoculated plants showed higher grain yield and total biomass in both cultivars and this increment was prominent in saline soil. Increase in grain yield than control under normal conditions in first year was $25-34 \%$ and in second year was $21-67 \%$, and under salinity conditions in first year was $22-45 \%$ and in second year was 45-67\%. Increase in total biomass under normal conditions in first year was 4-32\% and in second year was 5-23\%, and under salinity conditions, these rates for first and second year were $26-37 \%$ and $29-61 \%$, respectively. The highest total biomass and grain yield both in normal or salinity conditions were obtained from co-inoculated plants and Hashemi cultivar gained the higher rates than Gilane. This finding confirms importance of AMF symbiosis in growth improvement and yield of rice especially under stress conditions. Cause of the grain yield increase in inoculated plants may be attributed to nutrient uptake improvement and also, physiological changes like proline biosynthesis and enzymatic and non-enzymatic ROS scavenging pathway. These changes occurred in treated plants may be in relation to hormonal levels and enhanced uptake and translocation of water, and would translate into increased photosynthesis (Ruiz-Lozano and Aroca, 2010; Glick, 2014; Bhambure et al., 2018).

However, single inoculation of AMF and Pseudomonas species increased grain yield but the highest rates were observed in co-inoculated plants and their synergetic impact on grain yield and yield components was remarkable. These findings are same to that of Espidkar et al. (2017), Viollet et al. (2017) and Ansari et al. (2018). They demonstrated that colonization of AMF helper bacteria such as Pseudomonas, adhere to the root surface and improve AMF-plant symbiosis relations. Glick (2014) have presented main mechanisms of Pseudomonas spp in growth and yield increase of host plant as decrease in ethylene synthesis under environmental stresses, dissolution of $\mathrm{P}$ and $\mathrm{K}$ elements from soil resources and making them available for plant, and synthesis of phytohormones like Auxins and gibberellins. Impact of Pseudomonas spp. containing ACC-deaminase on grain yield increase under salinity stress has been confirmed by Arshad et al. (2008), Glick (2014), Bhambure et al. (2018), Yasmeen et al. (2019), Ma et al. (2019).

\section{Conclusions}

In both years and cultivars, the highest grain yield was obtained from co-inoculated plants and Hashemi cultivar was superior to Gilane in this regard. Higher grain yield in inoculated treatments may be due to increase in fertile tiller number, panicle number and grain per panicle. Microorganisms contributed to proline production and scavenging of $\mathrm{H}_{2} \mathrm{O}_{2}$ and reduction of growth limitations by improvement of environmental and physiological conditions of root and higher nutrient uptake. However, capability of AMF in developing water uptake by root surface should be considered. Inoculated treatments in most measured traits showed higher rates than control, bacterial inoculation raised efficiency of AMF and produced the highest grain yield and total biomass especially in Hashemi cultivar so, P.fluorescens + AMF + P.putida treatments are advisable for rice cropping under saline soils.

\section{Bibliographic References}

Aebi, H.E., 1983. Catalase, in: Bergemeyer H.U., (Ed.). Methods of enzymatic analysis. Verlag Chemie, Weinheim, p. 273-285.

Ahmadpour, R., Hosseinzadeh, S.R., Armand, N., 2016. Evaluation of methanol role in reducing the negative effects of water deficit stress in lentil (Lens culinaris Medik). Journal of Plant Process and Function, 5(17), 1-13.

Alguacil, M.M., Hernández, J.A., Caravaca, F., Portillo, B., Roldán, A., 2003. Antioxidant enzyme activities in shoots from three mycorrhizal shrub species afforested in a degraded semiarid soil. Physiology Plant, 118(4), 562-570.

Ali, Y., Aslam, Z., Ashraf, M.Y., Tahir, G.R., 2004. Effect of salinity on chlorophyll concentration, leaf area, yield and yield components of rice genotypes grown under saline environment. International Journal of Environmental Science and Technology, 1(3), 221-225. 
Ansari, M.H., Hashemabadi, D., Mahdavi, M., Kaviani, B., 2018. The role of pseudomonas strains and arbuscular mycorrhiza fungi as organic phosphate-solubilizing in the yield and quality improvement of strawberry (Fragaria $\times$ ananassa Duch., cv. Selva) fruit. Acta Scientiarum Polonorum. Hortorum Cultus, 17(4), 93-107.

Arnon, D.I., 1949. Copper enzymes in isolated chloroplasts. Polyphenoloxidase in Beta vulgaris. Plant Physiology, 24(1), 115.

Arshad, M., Shaharoona, B., Mahmood, T., 2008. Inoculation with Pseudomonas spp. containing ACC-deaminase partially eliminates the effects of drought stress on growth, yield and ripening of pea (Pisum sativum L.). Pedosphere, 18(5), 611620.

Asadi Rahmani, H., Khavazi, K., Asgharzadeh, A., Rejali, F., Afshari, M., 2012. Biofertilizers in Iran: Opportunities and challenges. Iranian Journal of Soil Research, 26(1), 77-87.

Atik, A., 2013. Effects of planting density and treatment with vermicompost on the morphological characteristics of Oriental Beech (Fagus orientalis Lipsky.). Compost Science and Utilization, 21, 87-98.

Augé, R.M., 2004. Arbuscular mycorrhizae and soil/plant water relations. Canadian Journal of Soil Science, 84(4), 373-381.

Bal, H.B., Nayak, L., Das, S., Adhya, T.K., 2013. Isolation of ACC deaminase producing PGPR from rice rhizosphere and evaluating their plant growth promoting activity under salt stress. Plant and Soil, 366(1-2), 93-105.

Bárzana, G., Aroca, R., Bienert, P., Chaumont, F., RuizLozano, J.M., 2014. New insights into the regulation of aquaporins by the arbuscular mycorrhizal symbiosis in maize plants under drought stress and possible implications for plant performance. Molecular Plant-Microbe Interactions, 27(4), 349-363.

Bárzana, G., Aroca, R., Paz, J.A., Chaumont, F., MartinezBallesta, M.C., Carvajal, M., Ruiz-Lozano, J.M., 2012. Arbuscular mycorrhizal symbiosis increases relative apoplastic water flow in roots of the host plant under both well-watered and drought stress conditions. Annals of Botany, 109(5), 10091017.

Bates, L.S., Waldren, R.P., Teare, I.D., 1973. Rapid determination of free proline for water-stress studies. Plant and soil, 39(1), 205-207.

Bhambure, A.B., Mahajan, G.R., Kerkar, S., 2018. Salt Tolerant Bacterial Inoculants as Promoters of Rice Growth and Microbial Activity in Coastal Saline Soil. Proceedings of the National Academy of Sciences, India Section B: Biological Sciences, 88(4), 1531-1538.

Bian, S., Jiang, Y., 2008. Reactive oxygen species, antioxidant enzyme activities and gene expression patterns in leaves and roots of Kentucky bluegrass in response to drought stress and recovery. Scientia Horticulturae, 120(2), 264-270.

Campanelli, A., Ruta, C., Mastro, G., Morone-Fortunato, I., 2013. The role of arbuscular mycorrhizal fungi in alleviating salt stress in Medicago sativa L. var. icon. Symbiosis, 59(2), 65-76.
Castillo, E.G., Toung, T.O., Phuc, A.M., Ismail, M., Inubushim, K., 2007. Response to salinity in rice: comparative effects of osmotic and Ionic stress. Plant Production Science, 10(2), 159170.

Chen, Y.Y., Hu, C.Y., Xiao, J.X., 2014. Effects of arbuscular mycorrhizal inoculation on the growth, zinc distribution and photosynthesis of two citrus cultivars grown in low-zinc soil. Trees, 28(5), 1427-1436.

Daei, G., Ardekani, M.R., Rejali, F., Teimuri, S., Miransari, M., 2009. Alleviation of salinity stress on wheat yield, yield components, and nutrient uptake using arbuscular mycorrhizal fungi under field conditions. Journal of plant physiology, 166(6), 617-625.

Demirevska, K., Simova-Stoilova, L., Vassileva, I., Vaseva, B., Grigorova, B., Feller, U., 2008. Drought-induced leaf protein alteration in sensitive and tolerant wheat varieties. Apply Plant Physiology Journal, 34(5), 79-10.

Emami, A., 1996. Plant analysis methods. Iranian Plant and Water Research Institute, No. 928 (In Farsi).

Espidkar, Z., Yarnia, M., Ansari, M.H., Mirshekari, B., Asadi Rahmani, H., 2017. Differences in nitrogen and phosphorus uptake and yield components between barley cultivars grown under arbuscular mycorrhizal fungus and pseudomonas strains co-inoculation in rainfed condition. Applied Ecology and Environmental Research, 15(4), 195-216.

Evelin, H., Giri, B., Kapoor, R., 2013. Ultrastructural evidence for AMF mediated salt stress mitigation in Trigonella foenumgraecum. Mycorrhiza, 23(1), 71-86.

Evelin, H., Kapoor, R., Giri, B., 2009. Arbuscular mycorrhizal fungi in alleviation of salt stress: a review. Annals of botany, 104(7), 1263-1280.

Fernández, F., Dellrsquo, J.M., Angoa, M.V., de la Providencia, I.E., 2011. Use of a liquid inoculum of the arbuscular mycorrhizal fungi Glomus hoi in rice plants cultivated in a saline Gleysol: A new alternative to inoculate. Journal of Plant Breeding and Crop Science, 3(2), 24-33.

Gay, F., Maraval, I., Roques, S., Gunata, Z., Boulanger, R., Audebert, A., Mestres, C., 2010. Effect of salinity on yield and 2-acetyl-1-pyrroline content in the grains of three fragrant rice cultivars (Oryza sativa L.) in Camargue (France). Field crops research, 117(1), 154-160.

Gianinazzi, S., Gollotte, A., Binet, M.N., van Tuinen, D., Redecker, D., Wipf, D., 2010. Agroecology: the key role of arbuscular mycorrhizas in ecosystem services. Mycorrhiza, 20(8), 519-530.

Glick, B.R., 2014. Bacteria with ACC deaminase can promote plant growth and help to feed the world. Microbiological research, 169(1), 30-39.

Grattan, S.R., Grieve, C.M., 1999. Mineral nutrient acquisition and response by plants grown in saline environments. Handbook of plant and crop stress, 2(1), 203-229.

Halder, M., Dhar, P.P., Mujib, A.S.M., Khan, M.S., Joardar, J.C., Akhter, S., 2015. Effect of Arbuscular Mycorrhiza Fungi Inoculation on Growth and Up take of Mineral Nutrition in Ipomoea Aquatica. Curr. World Environment, 10(1), 67-75. 
Han, H.S., Lee, K.D., 2005. Plant growth promoting rhizobacteria effect on antioxidant status, photosynthesis, mineral uptake and growth of lettuce under soil salinity. Research Journal of Agriculture and Biological Sciences, 1(3), 210-215.

Hasegawa, P.M., Bressan, R.A., Zhu, J.K., Bohnert, H.J., 2000. Plant cellular and molecular responses to high salinity. Annual review of plant physiology and plant molecular biology, 51(1), 463-499.

Hata, S., Sisaphaithong, T., Suzuki, S., Hanai, S., Tomioka, R., Kobae, Y., Tanaka, A., Yano, K., Takenaka, C., 2016. Varietal differences in growth promotion of rice (Oryza sativa) by an arbuscular mycorrhizal fungus. Abstracts of the $241^{\text {st }}$ Meeting of the Crop Science Society of Japan, 23.

Hoai, T.T.N., Shinm, I.S., Kobayashi, I.S., Usui, K., 2005. Regulation of ammonium accumulation during salt stress in rice (Oryza sativa L.) seedling. Plant Production Science, 8(4), 397 404.

Hosseini, S.J., Tahmasebi, Z., Pirdashti, H., 2012. Screening of rice (Oryza sativa L.) genotypes for $\mathrm{NaCl}$ tolerance at early seedling stage. International Journal of Agronomy and Plant Production, 3(8), 274-283.

Hosseinzadeh, S.R., Amiri, H., Ismaili, A., 2017. Nutrition and biochemical responses of chickpea (Cicer arietinum L.) to vermicompost fertilizer and water deficit stress. Journal of Plant Nutrition, 40(16), 2259-2268.

Ismail, A.M., Horie, T., 2017. Genomics, Physiology, and Molecular Breeding Approaches for Improving Salt Tolerance. Annual Review of Plant Biology, 68(1), 405-434.

Jan, Z., Ali, S., Sultan, T., Khan, M. J., Shah, Z., Khan, F. 2018. Impact of Different Strains of Cyanobacteria on Rice Crop Growth and Nutrients Uptake under Saline Soil Condition. Sarhad Journal of Agriculture, 34(2), 450-458.

Jha, Y., Subramanian, R.B., 2013. Paddy plants inoculated with PGPR show better growth physiology and nutrient content under saline condition. Chilean journal of agricultural research, 73(3), 213-219.

Jha, Y., Subramanian, R.B., 2015. Reduced cell death and improved cell membrane integrity in rice under salinity by root associated bacteria. Theoretical and Experimental Plant Physiology, 27(3-4), 227-235.

Jiang, Y., Wang, W., Xie, Q., Liu, N., Liu, L., Wang, D., Zhang, X., Yang, C, Chen, X., Tang, D., Wang, E., 2017. Plants transfer lipids to sustain colonization by mutualistic mycorrhizal and parasitic fungi. Science, 356(6343), 11721175.

Jogawat, A., Saha, S., Bakshi, M., Dayaman, V., Kumar, M., Dua, M., Varma, A., Oelmüller, A., Tuteja, N., Johri, A.K., 2013. Piriformospora indica rescues growth diminution of rice seedlings during high salt stress. Plant signaling and behavior, $8(10), 1-6$.

Kamyab-Talesh, F., Mousavi, S.F., Asadi, R., Rezaei, M., Khaledian, M.R. 2014. Evaluation of some rice cultivars' response to salinity stress using resistance indices. Archives of Agronomy and Soil Science, 60(9), 1303-1314.
Kaur, N., Dhawan, M., Sharma, I., Pati, P.K., 2016. Interdependency of Reactive Oxygen Species generating and scavenging system in salt sensitive and salt tolerant cultivars of rice. BMC plant biology, 16(1), 1-13.

Khaliq, A., Zia-ul-Haq, M., Ali, F., Aslam, F., Matloob, A., Navab, A., Hussain, S., 2015. Salinity tolerance in wheat cultivars is related to enhanced activities of enzymatic antioxidants and reduced lipid peroxidation. Clean-Soil, Air, Water, 43(8), 1248-1258.

Kibria, M.G., Hossain, M., Murata, Y., Hoque, M.A., 2017. Antioxidant Defense Mechanisms of Salinity Tolerance in Rice Genotypes. Rice Science, 24(3), 155-162.

Krajinski, F., Biela, A., Schubert, D., Gianinazzi-Pearson, V., Kaldenhoff, R., Franken, P., 2000. Arbuscular mycorrhiza development regulates the mRNA abundance of Mtaqp1 encoding a mercury-insensitive aquaporin of Medicago truncatula. Planta, 211(1), 85-90.

Lee, D.H., Kim, Y.S., Lee, C.B., 2001. The inductive responses of the antioxidant enzymes by salt stress in the rice (Oryza sativa L.). Journal of plant physiology, 158(6), 737-745.

Levine, A., Tenhaken, R., Dixon, R., Lamb, C., 1994. $\mathrm{H}_{2} \mathrm{O} 2$ from the oxidative burst orchestrates the plant hypersensitive disease resistance response. Cell, 79(4), 583-593.

Liu, T., Sheng, M., Wang, C.Y., Chen, H., Li, Z., Tang, M., 2015. Impact of arbuscular mycorrhizal fungi on the growth, water status, and photosynthesis of hybrid poplar under drought stress and recovery. Photosynthetica, 53(2), 250-258.

Loreto, F., Velikova, V., 2001. Isoprene produced by leaves protects the photosynthetic apparatus agent's zone damage, quenches ozone products and reduces lipid peroxidation of cellular membranes. Plant Phyiology, 127(4), 1781-1787.

Luginbuehl, L.H., Menard, G.N., Kurup, S., Van Erp, H., Radhakrishnan, G.V., Breakspear, A., Oldroyd, G.E.D. Eastmond, P.J., 2017. Fatty acids in arbuscular mycorrhizal fungi are synthesized by the host plant. Science, 356(6343), 1175-1178.

Ma, Y., Rajkumar, M., Oliveira, R.S., Zhang, C., Freitas, H., 2019. Potential of plant beneficial bacteria and arbuscular mycorrhizal fungi in phytoremediation of metal-contaminated saline soils. Journal of Hazardous Materials, 379, 120813.

Mathur, N., Vyas, A., 2000. Influence of arbuscular mycorrhiza on biomass production, nutrient uptake and mycorrhizal changes in Ziziphus mauritiana Lan. Under water stress. Journal of Arid Environments, 45(3), 191-195.

McWilliam, J.R. 1986. The national and international drought and salinity effects on agricultural production. Austarlian Journal of Plant Physiology, 13(1), 1-13.

Miller, G., Suzuki, N., Ciftci-Yilmaz, S., Mittler, R., 2010. Reactive oxygen species homeostasis and signalling during drought and salinity stresses. Plant Cell Environment, 33(4), 453-467.

Ministry of Jahad-e-Agriculture, 2018. Cultivation database. Bureau of Statistics and Information Technology, Deputy of Planning and Economic Affairs, Ministry of Jahad-eAgriculture, Iran. 
Mummey, D.L., Rillig, M.C., 2006. The invasive plant species Centaurea maculosa alters arbuscular mycorrhizal fungal communities in the field. Plant and Soil, 288(1-2), 81-90.

Nabiollahi, K., Taghizadeh-Mehrjardi, R., Kerry, R., Moradian, S., 2017. Assessment of soil quality indices for salt-affected agricultural land in Kurdistan Province, Iran. Ecological Indicators, 83, 482-494.

Navabian, M., Aghajani, M., 2012. Evaluating the Effect of Fresh and Saline Water Irrigation Management on Hashemi Rice Yield. Journal of Water and Soil Science, 16(60), 45-54.

Neto, M.C.L., Lobo, A.K.M., Martins, M.O., Fontenele, A.V., Silveira, J.A.G., 2014. Dissipation of excess photosynthetic energy contributes to salinity tolerance: a comparative study of salt-tolerant Ricinus communis and salt-sensitive Jatropha curcas. Journal of Plant Physiology, 171(1), 23-30.

Parvin, S., Van Geel, M., Yeasmin, T., Lievens, B., Honnay, O., 2019. Variation in arbuscular mycorrhizal fungal communities associated with lowland rice (Oryza sativa) along a gradient of soil salinity and arsenic contamination in Bangladesh. Science of The Total Environment, 686(1), 546-554.

Pellegrino, E., Turrini, A., Gamper, H.A., Cafa, G., Bonari, E., Young, J.P.W., Giovannetti M., 2012. Establishment, persistence and effectiveness of arbuscular mycorrhizal fungal inoculants in the field revealed using molecular genetic tracing and measurement of yield components. New Phytologist, 194(3), 810-822.

Ponnamperuma, F.N., Bandyopadhya, A.K., 1979. Soil salinity as a constraint on food production in the humid tropics, in: N.C. Brady, L.D. Swindale, R. Dudal (Eds.). Priorities for alleviating soil-related constraints to food production in the tropics. International Rice Research Institute. Los Baños, Laguna, p. 203216.

Porcel, R., Aroca, R., Azcón, R., Ruiz-Lozano, J.M., 2016. Regulation of cation transporter genes by the arbuscular mycorrhizal symbiosis in rice plants subjected to salinity suggests improved salt tolerance due to reduced $\mathrm{Na}$ root-to-shoot distribution. Mycorrhiza, 26(7), 673-684.

Porcel, R., Redondo-Gómez, S., Mateos-Naranjo, E., Aroca, R., Garcia, R., Ruiz-Lozano, J.M., 2015. Arbuscular mycorrhizal symbiosis ameliorates the optimum quantum yield of photosystem II and reduces non-photochemical quenching in rice plants subjected to salt stress. Journal of plant physiology, 185, 75-83.

Rahbarian, R., Khavari-nejad, R., Ganjeali, A., Bagheri, A.R., Najafi, F., 2011. Drought stress effects on photosynthesis, chlorophyll fluorescence and water relations in tolerant and susceptible chickpea (Cicer arietinum L.) genotypes. Acta Biologica Cracoviensia (Series Botanica), 53(1), 47-56.

Rahman, M.A., Thomson, M.J., Shah-E-Alam, M., Ocampo, M., Egdane, J., Ismail, A.M., 2016. Exploring novel genetic sources of salinity tolerance in rice through molecular and physiological characterization. Annals of botany, 117(6), 1083-1097.

Ruiz-Lozano, J.M., Porcel, R., Azcón, R., Aroca, R., 2012. Regulation by arbuscular mycorrhizae of the integrated physiological response to salinity in plants: new challenges in physiological and molecular studies. Journal of Experimental Botany, 63(11), 4033-4044.
Singh, D.P. Sarkar, R.K., 2014. Distinction and characterisation of salinity tolerant and sensitive rice cultivars as probed by the chlorophyll fluorescence characteristics and growth parameters. Functional plant biology, 41(7), 727-736.

Smith, F.A., Grace, E.J., Smith, S.E., 2009. More than a carbon economy: nutrient trade and ecological sustainability in facultative arbuscular mycorrhizal symbioses. New Phytologist, 182(2), 347-358.

Smith, S.E., Read, D.J., 2008. Mycorrhizal symbiosis, third ed. Academic, London.

Talaat, N.B., Shawky, B.T., 2011. Influence of arbuscular mycorrhizae on yield, nutrients, organic solutes, and antioxidant enzymes of two wheat cultivars under salt stress. Journal of Plant Nutrition and Soil Science, 174(2), 283-291.

Tofighi, C., Khavari-Nejad, R.A., Najafi, F., Razavi, K., Rejali, F., 2017. Responses of wheat plants to interactions of 24epibrassinolide and Glomus mosseae in saline condition. Physiology and molecular biology of plants, 23(3), 557-564.

Van Der Heijden, M.G., 2010. Mycorrhizal fungi reduce nutrient loss from model grassland ecosystems. Ecology, 91(4), 11631171

Vázquez, M.M., Barea, J.M., Azcón, R., 2002. Influence of arbuscular mycorrhizae and a genetically modified strain of Sinorhizobium on growth, nitrate reductase activity and protein content in shoots and roots of Medicago sativa as affected by nitrogen concentrations. Soil Biology and Biochemistry, 34(7), 899-905

Vessey, J.K., 2003. Plant growth promoting rhizobacteria as biofertilizers. Plant and Soil, 255(2), 571-586.

Viollet, A., Pivato, B., Mougel, C., Cleyet-Marel, J.C., GubryRangin, C., Lemanceau, P., Mazurier, S., 2017. Pseudomonas fluorescens C7R12 type III secretion system impacts mycorrhization of Medicago truncatula and associated microbial communities. Mycorrhiza, 27(1), 23-33.

Watanarojanaporn, N., Boonkerd, N., Tittabutr, P., Longtonglang, A., Young, J.P.W., Teaumroong, N., 2013. Effect of rice cultivation systems on indigenous arbuscular mycorrhizal fungal community structure. Microbes and environments, 28(3), 316324.

Yan, N., Marschner, P., Cao, W., Zuo, C., Qin, W., 2015. Influence of salinity and water content on soil microorganisms. International Soil and Water Conservation Research, 3(4), 316323.

Yasmeen, T., Tariq, M., Iqbal, S., Arif, M.S., Riaz, M., Shahzad, S.M., Ali, S., Noman, N., Li, T., 2019. Ameliorative Capability of Plant Growth Promoting Rhizobacteria (PGPR) and Arbuscular Mycorrhizal Fungi (AMF) Against Salt Stress in Plant, in: Plant Abiotic Stress Tolerance. Springer, Cham, p. 409-448.

Zeng, L., Lesch Scott, M., Grieve Catherine, M., 2003. Rice growth and yield respond to changes in water depth and salinity stress. Agricultural Water Management, 59(1), 67-75.

Zhang, S.J., Wang, L., Ma, F., Bloomfield, K.J., Yang, J.X., Atkin, O.K., 2015. Is resource allocation and grain yield of rice altered by inoculation with arbuscular mycorrhizal fungi? Journal of Plant Ecology, 8(4), 436-448. 
42 Alleviation of soil salinity on rice cultivars physiological and agronomic traits using Arbuscular mycorrhizal fungi and...

Zhang, Z.H., Liu, Q., Song, H.X., Rong, X.M., Abdelbagi, M.I., 2010. Responses of different rice (Oryza sativa L.) genotypes to salt stress and relation to carbohydrate metabolism and chlorophyll content. African Journal of Agricultural Research, 7(1), 19-27.
Zhu, X.Q., Wang, C.Y., Chen, H., Tang, M., 2014. Effects of arbuscular mycorrhizal fungi on photosynthesis, carbon content, and calorific value of black locust seedlings. Photosynthetica, 52(2), 247-252. 